\title{
O DIREITO CONSTITUCIONAL TRIBUTÁRIO BRASILEIRO PELAS MÃOS DE JOSÉ ROBERTO VIEIRA
}

\section{THE BRAZILIAN CONSTITUTIONAL TAX LAW BY JOSÉ ROBERTO VIEIRA'S HANDS}

\author{
Maurício Dalri Timm do Valle \\ Universidade Católica de Brasília - UCB - (Brasília, DF, Brasil)
}

Recebimento: 13 set. 2017

Aceitação: 20 set. 2017

\begin{abstract}
Como citar este artigo / How to cite this article (informe a data atual de acesso / inform the current date of access):
VALLE, Maurício Dalri Timm do. O direito constitucional tributário brasileiro pelas mãos de José Roberto Vieira. Revista da Faculdade de Direito UFPR, Curitiba, PR, Brasil, v. 62, n. 3, p. 285-322, set./dez. 2017. ISSN $2236-7284$. Disponível em: <http://revistas.ufpr.br/direito/article/view/55219>. Acesso em: 21 dez. $2017 . \quad$ DOI: http://dx.doi.org/10.5380/rfdufpr.v62i3.55219.
\end{abstract}

\section{RESUMO}

O presente artigo tem por objetivo expor o direito constitucional tributário brasileiro a partir das obras de José Roberto Vieira. No ano em que o professor da Universidade Federal do Paraná completa 65 anos, tentou-se sistematizar sua obra, composta por livros, capítulos de livros, artigos e prefácios. Depois do exame de toda a sua obra, foram selecionados os principais temas do direito constitucional tributário - tais como a interpretação do direito, a noção de sistema no direito, o poder tributário, a competência tributária e suas características, a criação constitucional do tributo, os princípios constitucionais gerais (república, federação, tripartição das funções e autonomia dos municípios), os princípios constitucionais específicos (legalidade, anterioridade, irretroatividade, igualdade, capacidade contributiva e suas relações com a extrafiscalidade e com a praticabilidade, seletividade e não-cumulatividade) e as funções da lei complementar - para, num segundo momento, descrever os posicionamentos de José Roberto Vieira acerca de cada um dos temas. Concluiu-se que José Roberto Vieira contribuiu significativamente, inovando em determinados temas, para o desenvolvimento da ciência do direito tributário brasileiro, e, especialmente, para a escola de direito tributário do Paraná, da qual ele é, sem dúvida, o grande nome.

\section{PALAVRAS-CHAVE}

Direito constitucional tributário. Competência tributária. Princípios constitucionais tributários. Funções da lei complementar.

\begin{abstract}
This article aims to expose the Brazilian Tax Constitutional Law from the works of José Roberto Vieira. In the year in which the Professor of the Federal University of Paraná turns 65, an attempt was made to systematize his work, composed of books, chapters of books, articles and prefaces. After examining all of his work, the main themes of the constitutional tax law were selected - such as the interpretation of law, the notion of system in law, tax power, tax competence and its characteristics, constitutional creation of tax, the General Constitutional Principles (Republic, Federation, Tripartition of Functions and Autonomy of Municipalities), the specific constitutional principles
\end{abstract}


(Legality, Priority, Irretroactivity, Equality, Contribution Capacity and its relations with extrafiscality and with practicability, Selectivity and Non-cumulativity) and the functions of the complementary law - to, in a second moment, describe the positions of José Roberto Vieira on each of the themes. It was concluded that José Roberto Vieira contributed significantly, innovating in certain subjects, to the development of the science of Brazilian tax law, and especially to the School of Tax Law of Paraná, where he is undoubtedly the great name.

\section{KEYWORDS}

Constitutional tax law. Tax competence. Constitutional tax principles. Functions of the complementary law.

\section{INTRODUÇÃO}

Quando nos deparamos com a obra de José Roberto Vieira, percebemos que seus artigos e livros, quando estudados sistematicamente, são, em verdade, um profundo curso de direito constitucional tributário. Não só de tributário, é bem verdade. Com a leitura de seus escritos aprendemos muito de língua portuguesa, de filosofia e de literatura. Possui excelente produção bibliográfica do ponto de vista quantitativo e, principalmente, qualitativo. Nela, realiza análises que partem tanto da teoria quanto do viés prático. Afasta-se das posturas tanto dos "teóricos inflexíveis" quanto dos "práticos extremados", lembrando que "A única alternativa verdadeiramente científica está na confluência de ambos os polos do conhecimento”. Parte da premissa que “...o conhecimento humano não admite que se aparte a teoria da prática”. E, em razão disso, “...só se pode afirmar conhecido um objeto quando o seu domínio é tanto teórico quanto prático" (VIEIRA, 1998, p. 535, grifo do autor).

Em 2017, José Roberto Vieira, professor que influenciou gerações, completa sessenta e cinco anos de vida e quinze como professor do Programa de Pós-Graduação em Direito da Universidade Federal do Paraná. Este breve escrito pretende, então, descrever, de forma sistemática, o entendimento dele acerca dos principais temas do direito constitucional tributário, tais como a interpretação, a noção de sistema no direito, a competência tributária, os princípios constitucionais tributários e as funções da lei complementar em matéria tributária.

\section{SOBRE A INTERPRETAÇÃO}

De acordo com José Roberto Vieira, “O Direito Positivo constitui uma linguagem que se direciona à conduta intersubjetiva, com intuito prescritivo”. A Ciência do Direito, por sua vez, teria “...índole cognoscitiva e descritiva” (VIEIRA, 2002a, p. 90). Observamos, entretanto, que a atividade 
do cientista do direito não se limita à mera descrição do direito positivo. Segundo ele, vai além (VIEIRA, 2000, p. 60). Em suas palavras:

Convém esclarecer que não entendemos o descrever típico da ciência jurídica num sentido estrito, como "expor, contar minuciosamente...", do latim "describere", mas num sentido lato, como explicar, como "tornar inteligível, interpretar...”, do latim "explicare” (Antônio Geraldo da Cunha); como "tornar claro o que até então estava obscuro, porque envolvido, encoberto", como retirar das plicas (dobras) - "ex-plicare" - o que ali se encontrava oculto; de conformidade com a lição competente de José Souto Maior Borges (VIEIRA, 2002a, p. 90).

José Roberto Vieira, neste particular, segue as lições de José Souto Maior Borges, que inicia a análise da atividade do cientista do direito identificando a não unanimidade de entendimento no concernente ao significado de sua descritividade. Realmente, como visto, é praticamente unânime a ideia de que o conteúdo das proposições do cientista do direito é descritivo, mas, de forma alguma, são pacíficas as concepções a respeito dessa descritividade. Diante disso, Souto Maior Borges adverte que, se for considerada tarefa da Ciência do Direito a mera descrição de normas, seria, a sua atividade, supérflua. Além disso, chama a atenção para o fato de que não se deve confundir a descrição como função cognoscitiva da Ciência do Direito com a descrição contida na hipótese de incidência das normas. Feitas essas recomendações, Souto Maior Borges sustenta que se pode atribuir à função descritiva da Ciência do Direito uma ampla gama de significações, tais como, “...comentar, interpretar, descrever em sentido estrito, enunciar, formular hipóteses e deduzir-lhes as implicações, generalizar, expor...”, ou seja, o termo descrição deve ser entendido da forma mais abrangente possível. Em seguida, conclui que à Ciência do Direito não cabe meramente descrever o Direito Positivo, mas sim, utilizando-se de metodologia própria, explicá-lo. Certo de que, para se apreender a real significação, que é encoberta pela questão terminológica, mostra-se necessária uma escavação etimológica de ambos os termos - explicar e descrever -, Souto Maior Borges analisa-os. Inicia pela etimologia do termo “explicar”. Ensina que explicar deriva do latim “explicare”, cuja significação é “...despregar, desdobrar, desenvolver, justificar, interpretar, expor, comentar, explanar [...] esclarecer, aclarar, elucidar". É palavra formada pelo prefixo "ex” e pela palavra "plicare”. O prefixo "ex" tem a mesma função do prefixo “des”, qual seja, denotar separação ou mudança de estado. "Plicare”, por sua vez, significa pregar “...no sentido de fazer pregas ou plicas”. "Plica” significa dobra. "Dobra” possui a mesma raiz etimológica de "dobro", e ambos correspondem a “duplo”, “duplicar”. Assim, “explicar” é o mesmo que "des-duplicar”, ou seja, descobrir ou clarear o que estava escondido na escuridão das plicas (dobras). Nas ciências da natureza as plicas estão nos fenômenos naturais, enquanto, na Ciência do Direito, “...encontram-se num fenômeno lingüístico”. “Descrever”, por sua vez, deriva do latim “describere”, cuja significação é “...expor, narrar, referir 
com certo desenvolvimento, delinear...”. Significação um tanto quanto limitada, se comparada àquela do termo "explicar”. Souto Maior Borges afirma que, se fosse elevado o grau de precisão terminológica, sob o gênero "proposições cognoscentes do direito positivo” estariam contidas tanto “proposições explicativas” quanto “proposições descritivas”. Entretanto, a utilização frequente da expressão “proposições descritivas” permite a continuidade de seu uso, desde que atentemos para o fato de que sua significação é abrangente (BORGES, 2000, p. 123-127).

Ao tratar da tarefa exegética, José Roberto Vieira lembra-nos da possibilidade de interpretarmos o direito como um corpo de linguagem. Para ele, “...a linguagem é a capacidade do ser humano para comunicar-se através de signos...”, que são “...a unidade primeira do sistema”. E, partindo dos ensinamentos de Charles Sanders Peirce, identifica o "signo" como uma relação trinitária, cogitando, então, o “...suporte físico (a palavra falada ou escrita, em termos linguísticos), significado (o objeto do mundo) e significação (a noção que nos é suscitada)...”. E, no Direito, a analogia seria perfeitamente possível: “Dos textos legais (suportes físicos); que se voltam para um objeto do mundo - a conduta humana intersubjetiva (significado) - buscando discipliná-la, extraímos os juízos que correspondem às normas jurídicas (significações)”. Diz mais: que a análise da linguagem prescritiva do direito deve percorrer os três planos das investigações semióticas, quais sejam, o sintático (relações dos signos entre si), o semântico (relações dos signos com os seus significados) e o pragmático (relações dos signos com seus usuários) (VIEIRA, 1993, p. 50-52).

No plano sintático, encontram-se as relações dos signos entre si. Nas investigações desenvolvidas neste plano não há lugar para o exame das designações dos signos, tampouco de suas relações com seus usuários. Ao aplicá-lo ao campo jurídico, Luís Alberto Warat afirma que “...uma expressão está sintaticamente bem formada quando o enunciado acerca de uma ação encontra-se deonticamente modalizado". O plano semântico limita-se a estudar as relações que os signos mantêm com os objetos aos quais se referem, ou melhor, com seus significados. Quando examinamos o sentido do vocábulo empregado pelo legislador, a análise desempenhada é a do plano semântico. O plano pragmático detém-se no estudo das relações dos signos com seus usuários, com os utentes da linguagem (WARAT, 1995, p. 40-45).

Em outro escrito, José Roberto Vieira trata, brevemente, dos métodos, meios, técnicas ou processos de interpretação. Partindo da interpretação literal, gramatical ou filológica, visitando os métodos histórico, lógico e teleológico, para, enfim, alcançar a interpretação sistemática. Fica claro, da leitura do texto, que a interpretação é única. O que pode variar são os métodos ou meios empregados para construí-la. É bem verdade que "Embora conjuntamente aplicáveis, é possível identificar a etapa e as providências que correspondem a cada uma dessas técnicas...”. E José 
Roberto Vieira assim o faz, ao afirmar: “...julgamos indispensável ao estudo que faremos, estabelecer, ao menos, uma radical hierarquia, apontando o método literal como o mais pobre, mísero e estéril deles, e identificando o método sistemático como o mais opulento, fértil e fecundo de todos” (2002a, p. 91-93). Sobre os dois métodos, escreve:

A interpretação literal é inevitável como início do processo hermenêutico [...], pois os textos legais correspondem ao ponto de partida necessário da atividade interpretativa [...]. Nada mais do que isso, porém: ponto de partida e porta de entrada. Se nela nos detivermos, satisfazendo-nos com a literalidade textual, nossa corrida hermenêutica não terá ido além da linha de saída, nossa aventura exegética não terá ultrapassado os limiares do acesso, não terá transposto os umbrais do pórtico da terra da interpretação, que principia dali em diante, do texto avante. [...]

Já a interpretação sistemática, ancha e larga, compreende os métodos literal e lógico, no plano sintático da linguagem, bem como os métodos histórico e teleológico, nos planos semântico e pragmático da linguagem; ou seja, a visão sistemática não só percorre todos os níveis da linguagem do direito posto, como também demanda e pressupõe todos os demais métodos interpretativos. [...] Nessa técnica, não só ingressamos por inteiro no país hermenêutico, mas examinamos todos os seus cantos, analisamos todos os seus recantos, perscrutamos todas as suas sombras; passamos pelo texto sim, mas muito além, mergulhamos fundo e demoradamente no seu contexto (2002a, p. 92-93).

E, encerra seus ensinamentos sobre o tema: “Com frequência, a interpretação literal deparase, à guisa de resultado, com vazios e frustrantes favos de vespa. Amiúde, a interpretação sistemática surpreende, como recompensa de seu labor, repletos e apetitosos favos de abelha” (2002a, p. 93).

\section{SOBRE A NOÇÃO DE SISTEMA NO DIREITO}

Acerca da noção de sistema, José Roberto Vieira escreveu o “A noção de sistema no direito” (2000, p. 53-64), publicado na Revista da Faculdade de Direito UFPR. Logo na primeira página do artigo, podemos identificar a presença de dois temas interessantíssimos: a diferença entre “ordenamento jurídico” e “sistema jurídico” e a “polissemia dos vocábulos”. Logo após tratar das diversas "noções de sistema” - iniciando pela noção primeira, em que sistema é entendido como um conjunto de objetos, que é chamado de "repertório”, mais as suas relações, de acordo com certas regras, ao que se chama "estrutura”; passando pela noção segunda, na qual presente, além do repertório e da estrutura, também a "unidade”, ou seja, os elementos relacionar-se-iam, formando um todo unitário; finalizando na noção terceira de sistema, na qual se soma a característica da “ordenação” ou da “coerência” - José Roberto Vieira examina a “coerência” e as diferenças entre a “Ciência do Direito” e o Direito Positivo”, bem como as lógicas que os informam, ou seja, a “lógica clássica” e a "lógica deôntica”, concluindo que tanto a Ciência do Direito quanto o Direito Positivo são sistemas. São suas palavras: 
Mencionávamos, há pouco, três noções possíveis de sistema. A primeira (repertório e estrutura), insuficiente. A segunda (repertório, estrutura e unidade), bastante para explicá-lo no nível do Direito Positivo. A terceira (repertório, estrutura, unidade e coerência), apta a significá-lo na esfera da Ciência do Direito (2000, p. 61, grifo do autor).

O interessante é que um pouco antes de lançar a sua conclusão, José Roberto Vieira reconhece ter mudado de opinião em relação àquilo que defendia. No artigo, expressamente manifestou-se no sentido de “...embora destituído de plena coerência, o direito posto é sistema pelas razões que passamos brevemente a enunciar” (2000, p. 59). Antes, em 1993, em seu clássico “A regra-matriz de incidência do IPI: texto e contexto”, mencionava que “...o ordenamento aponta na direção de ser sistema; mas, aditamos agora, não logrará sê-lo, em última instância. Apenas e tão somente à Dogmática Jurídica (ciência jurídica em sentido estrito) é dado atingir tal nível, porque isenta das contradições que não poupam o conjunto das normas positivadas” (1993, p. 33-35, grifo do autor).

\section{SOBRE A CRIAÇÃO DO TRIBUTO E A COMPETÊNCIA TRIBUTÁRIA}

\subsection{EXISTE UM PODER TRIBUTÁRIO?}

O Legislador Constitucional denominou a Seção II do Capítulo I do Título VI da Constituição Federal de 1988 como “Das limitações do poder de tributar”. Mostra-nos José Roberto Vieira que a doutrina estrangeira e a nacional denominavam a possibilidade de instituir e de exigir tributos como um “poder”, ligado diretamente à soberania do Estado. E que, em contraposição a esse entendimento, formou-se doutrina que apartava o exame do poder tributário da ideia de soberania. Mas mesmo dissociado da ideia de soberania, a noção de “poder tributário” continuava imprecisa. Algo inaceitável dentro de um discurso que se pretendia científico (2005c, p. 610-618). José Roberto Vieira alerta para o fato de que a “...heterogeneidade da expressão 'poder' tributário aponta para a atitude cientificamente condenável - pela inexatidão manifesta - de admitir a convivência de diferentes funções e competências dentro da mesma categoria conceptual...” e, seguindo os passos da doutrina estrangeira, debruça-se sobre o "poder tributário” a fim de melhor descrever os diversos significados que lhe foram atribuídos pela doutrina (2005c, p. 615). De acordo com ele, Renato Alessi separou o poder tributário em potestade tributária primária e em potestade tributária complementar. A primeira referia-se à ação de editar normas jurídicas com o escopo de estabelecer tributos, enquanto a segunda se ligava à aplicação da norma que os instituiu, o que demonstrava seu caráter administrativo. Continua, expondo que coube a Gian Antonio Micheli desenvolver a distinção, separando o poder tributário em Potestade Normativa Tributária - que nada mais era do que a 
possibilidade de o Estado legislar, em matéria tributária, criando e regulando as prestações com essa índole - de um lado, e em Potestade de Imposição - aplicação pelo Estado das normas anteriormente criadas, a fim de alcançar a prestação tributária, atividade caracteristicamente administrativa - de outro. Mencionou, ainda, Antonio Berliri, para quem "Potestade tributária” referia-se à atividade legislativa, e “Potestade regulamentar da administração pública em matéria tributária”, por sua vez, aludia à atividade administrativa; e, por fim, trouxe à baila o entendimento de Albert Hensel, que se valia da expressão “Poder tributário” para se referir à possibilidade de abstratamente criar o tributo, e de Competência para a atividade administrativa destinada a ver satisfeita a exigência. Inegavelmente, o José Roberto Vieira demonstrou o que, em suas próprias palavras, chama de “...grande variação terminológica...” que experimenta o tema (2005c, p. 616-618).

Mas existe um "Poder tributário"?

Diz José Roberto Vieira que é equivocada a menção a um poder tributário cujos titulares seriam as pessoas políticas União, estados, Distrito Federal e municípios (2005c, p. 610). Dotada de “poder” - fosse ele de qualquer espécie, inclusive tributário - estava a Assembleia Nacional Constituinte, que, por lançar a pedra fundamental do sistema jurídico brasileiro - a Constituição Federal de 1988 -, gozava de ampla liberdade para estabelecer as prescrições primeiras do sistema jurídico. Esgotado o exercício do mencionado poder, o que restou foram suas parcelas. Às parcelas desse “poder tributário”, distribuídas entre as pessoas políticas, dá-se o nome de “competência tributária”1.

\subsection{A CONSTITUIÇÃO CRIA O TRIBUTO}

Lembremos, com José Roberto Vieira e com Diego Marín Barnuevo Fabo, que a competência tributária é “...rígida e integralmente estabelecida na Constituição Brasileira, distribuindo-se pelas três esferas de governo, em virtude dos Princípios Constitucionais da Federação e da Autonomia dos Municípios” (1997, p. 96).

A competência tributária é usualmente conceituada pela doutrina como a aptidão ou faculdade para “criar" abstratamente o tributo, observando-se o procedimento previsto na Constituição para tanto. Isso, claro, se a considerarmos - como o faz parte da doutrina - como norma permissiva dirigida ao legislador, para que institua, por meio de lei, geralmente ordinária,

\footnotetext{
${ }^{1}$ Lembremos, com José Roberto Viera, que inexistem reais conflitos de competência. Diz ele: “Resumindo, pois, os propalados 'conflitos de competência' não passam da ilusão que fascina, da aparência que seduz, porque, afinal, nada mais são do que conflitos de leis geradas - aqui, o real jurídico desmascarado, aqui, a realidade constitucional desembuçada - por conflitos interpretativos" (2013b, p. 60, grifo do autor).
} 
abstratamente, o tributo. Nessa concepção, permite-se ao legislador que institua uma obrigação espécie de modal deôntico (2005c, p. 639).

Cabe, aqui, entretanto, lançar um questionamento: a competência tributária é a aptidão para que o legislador infraconstitucional crie, em abstrato, o tributo, ou apenas institua o tributo, completando a sua regra-matriz de incidência, a partir dos elementos indispensáveis já presentes no texto constitucional?

A maioria da doutrina sustenta que a Constituição Federal não cria tributos, limitando-se a distribuir competências entre as pessoas políticas para que elas o façam.

José Roberto Vieira defendia, em sua obra “A regra matriz de incidência do IPI: texto $e$ contexto”, que, apesar de toda regra jurídica encontrar seu fundamento de validade na Constituição Federal, o fato de buscar a lei ordinária instituidora do tributo seu fundamento de validade na Constituição Federal não autorizava a afirmação de que a criação do tributo teve início já no texto constitucional. Nessa obra, de 1993, José Roberto Vieira defendia que a Constituição não cria tributos, limitando-se à distribuição de competências (1993, p. 43-46). Em 2005, disse José Roberto Vieira curvar-se “... diante da rica e bem posta argumentação do mestre” José Souto Maior Borges. (2005c, p. 605-606). Nessas páginas, ele demonstra os motivos que o levaram a reformular seu entendimento (2005c, p. 630-641). Principia realizando a análise etimológica do verbo “criar” e do substantivo “criação”, informando-nos que os léxicos apontam como paralelos “...gerar, formar, produzir, inventar, instituir, [...] 'dar existência a' e 'tirar do nada’”. Em seguida, caminha pelas sendas dos dicionários de filosofia e percebe que eles confirmam as acepções de “criar” e "criação” dos léxicos. Conclui, entretanto, que, ao Direito - por ser objeto cultural, fruto da construção humana -, aplica-se somente a primeira acepção - “dar existência a” - na medida em que a segunda - "tirar do nada”, ou ainda, “creatio ex nihilo” - refere-se à atividade divina. Diante disso, vale a pena transcrever uma das conclusões a que chegou:

E muito embora se fale em algo que nunca teria existido antes, marcado pela originalidade, frise-se que o grau de novidade será sempre relativo, seja em virtude do fato de que uma instituição jurídica nova se caracteriza como tal somente no recinto bem delimitado de um certo ordenamento, cujo âmbito de validade se encerra em fronteiras precisas, tanto espaciais quanto temporais, seja em função dos próprios limites inerentes à condição humana. Nesse sentido, encontramos criação do Direito em todos os níveis da hierarquia das leis, desde a constituição até os atos administrativos ou judiciais. Não obstante prefiram os juristas sempre falar, aqui, de aplicação do Direito, inegavelmente é concomitante a idéia de sua produção (2005c, p. 633).

Lembremo-nos que o referencial teórico do qual parte José Roberto Vieira são os ensinamentos de Hans Kelsen. Com base neles, relembra que, voltando-se os olhos para qualquer 
ponto do sistema jurídico, encontramos tanto atos de aplicação do Direito (execução) como também atos de criação (produção normativa), aparecendo um ou outro, a depender do ponto a partir do qual se mire. Ao se olhar o sistema a partir de seu ponto mais elevado, vê-se uma série de processos de produção (criação) do Direito. Se, ao contrário, olharmos a partir da base, deparar-nos-emos com uma série de processos de execução jurídica. Isso só não acontece quando direcionamos o foco da visão aos pontos limites do sistema. Ao contemplarmos a Constituição Federal, encontraremos somente ato de produção do Direito. Do contrário, se focalizarmos um ato final de execução, nele não encontraremos qualquer pretensão de criação ou produção jurídica (2005c, p. 634-635).

Forte nessas premissas, José Roberto Vieira analisa os dois argumentos principais manejados por aqueles que entendem que a constituição não cria o tributo. Ao primeiro dos seus argumentos de que não lhe parecia correto afirmar que o direito positivo estivesse por completo contido no corpo da Constituição - responde, José Roberto Vieira, que aqueles que defendem a criação do tributo pela Constituição seguem à risca os ensinamentos de Hans Kelsen, na medida em que entendem serem previstos pela Constituição, até certa medida - não de forma exaustiva -, os órgãos responsáveis pela criação do Direito e seu processo. Até mesmo porque a Constituição, como lei suprema de determinado sistema jurídico, possui um grau de abstração muito maior do que as leis que a venham a aplicar. Contra o segundo argumento - de que a sentença judicial, apesar de buscar seu fundamento de validade na Constituição, não é criada pelo Legislador Constitucional - pondera José Roberto Vieira que, embrionariamente, as sentenças e atos judiciais encontram espaço na Constituição, concluindo que “...como entidades jurídicas acabadas, sentença e ato não foram criados na constituição; como mínimo essencial daquelas entidades jurídicas, sentença e ato começaram a ser criados na constituição sim” (2005c, p. 635-637).

Conclui, então, José Roberto Vieira que a Constituição cria o “...tributo mínimo...”, ressaltando que o processo de criação do tributo é iniciado com a outorga de competências, e que, mesmo sendo os dispositivos constitucionais insuficientes para o desenho completo do tributo, não quer isso dizer que sejam, tais dispositivos constitucionais, inexistentes (2005c, p. 639-640). Os dados essenciais da norma jurídica de incidência dos tributos são apresentados já na Constituição.

Sobre esse posicionamento, adverte José Roberto Vieira que ele não deve ser apreendido literalmente, na medida em que a Constituição Federal não concebe o tributo em sua totalidade, apto a, desde logo, incidir, caso ocorra o fato hipoteticamente descrito na hipótese de incidência da norma tributária e, com isso, desencadear a relação jurídica tributária correspondente (2005c, p. 621). À lei ordinária que institui o tributo cabe, além dos elementos essenciais dispostos pela Constituição 
Federal - hipótese de incidência, sujeitos da relação jurídica (ativo e passivo) e base de cálculo -, detalhá-los e prescrever quais serão as alíquotas aplicáveis.

\subsection{AS CARACTERÍSTICAS DA COMPETÊNCIA TRIBUTÁRIA}

As características da competência tributária também foram objeto de exame por parte de José Roberto Vieira (2005c, p. 622-624). Lembremos que a doutrina atribui à competência tributária seis características: i) indelegabilidade; ii) irrenunciabilidade; iii) incaducabilidade; iv) inalterabilidade; v) privatividade; e vi) facultatividade.

José Roberto Vieira manifesta-se no sentido de acatar, “...sem quaisquer disceptações, a indelegabilidde e a irrenuciabilidade...” como características da competência tributária (2005c, p. 622). A “indelegabilidade” é a impossibilidade de a pessoa política que recebeu da Constituição Federal competência para instituir determinado tributo transferi-la para outra pessoa política, seja a que título for. José Roberto Vieira afirma ser a irrenunciabilidade a “...impossibilidade de abdicação em caráter definitivo" da competência tributária (2005c, p. 622). A “incaducabilidade” decorre do fato de que o não exercício da competência tributária, por longo período de tempo, não a extingue. O decurso do tempo não é circunstância que impede a pessoa política titular da competência tributária de exercitá-la. Logo, a competência tributária é incaducável. O fato de haver tributos com prazos de vigência fixos, com data constitucionalmente fixada para se extinguirem - a exemplo do IPMF e da CPMF -, não retira da competência tributária a característica da incaducabilidade. De acordo com José Roberto Vieira, esses são tributos adicionados à competência tributária de um dos entes da Federação. A competência estabelecida originariamente pela Constituição é incaducável. Se assim não o fosse, a autonomia da União, dos estados ou dos municípios restaria prejudicada, e, em consequência disso, também o Princípio Federativo - cláusula pétrea integrante do rol do $\S 4^{\circ}$ do artigo 60, da Constituição Federal de 1988 -, como também ferido seria o Princípio da Autonomia Municipal, cuja mácula autoriza até mesmo a intervenção federal nos estados que o descumpram, conforme prescreve o artigo 34, VII, “c”, da Constituição Federal de 1988 (2005c, p. 623). A “inalterabilidade”, como parece óbvio, é característica que demonstra que a competência tributária não pode ser alterada. Ao examiná-la, José Roberto Vieira ressalta sua relatividade, tomando-se em conta o ponto de vista do qual partamos. Se for o da pessoa política destinatária da competência tributária, será a competência tributária inalterável. Entretanto, se analisada a partir da possibilidade de reforma constitucional por meio de emenda, será alterável (2005c, p. 623). Há quem argumente que a competência reformadora poderá, desejando, realizar alterações no quadro discriminativo das 
competências tributárias; e, ainda, que tanto as constituições dos estados quanto as leis orgânicas dos municípios podem - aumentando as garantias dos contribuintes, e prevendo, por exemplo, o Princípio da Anualidade - comprimir a competência tributária que lhe foi outorgada, alterando-a. Rebatendo esses argumentos, José Roberto Vieira entende não serem suficientemente aptos a arredar a inalterabilidade como uma das características da competência tributária. Em seu entender, é circunstância de autolimitação da competência, permitida, inclusive, em razão de outra característica sua, a facultatividade (2005c, p. 623). Com relação à “privatividade”, José Roberto Vieira entende-a como característica da competência tributária com base em dois fortes argumentos. A única competência tributária privativa seria a da União. E para alcançar essa conclusão, invoca o artigo 154, II, da Constituição Federal, o qual prescreve que “...a União poderá instituir [...] na iminência ou no caso de guerra externa, impostos extraordinários, compreendidos ou não em sua competência tributária, os quais serão suprimidos gradativamente, cessadas as causas de sua criação”. Percebemos, da leitura desse dispositivo constitucional, que há circunstâncias - iminência ou caso de guerra externa - nas quais a União está constitucionalmente autorizada a invadir a esfera de competência dos estados e dos municípios. Poderá, portanto, em determinados casos, exercer, a União, competência tributária que a Constituição atribuiu a estados e municípios. Se outra pessoa política, que não o município, pode exercer a competência tributária que a Constituição lhe outorgou, e se outra pessoa política, além do estado, pode exercer a competência tributária que lhe foi atribuída pela Constituição, não há que se falar em privatividade, ao empreender-se a caracterização da competência tributária dessas duas pessoas políticas. Desse ponto de vista, privativa mesmo, somente a competência tributária da União. O outro argumento é o da cumulatividade de competências nas mãos da União, nos casos previstos pelo artigo 147 da Constituição Federal (2005c, p. 624). Prescreve o citado artigo que “...competem à União, em Território Federal, os impostos estaduais e, se o Território não for dividido em Municípios, cumulativamente os impostos municipais; ao Distrito Federal cabem os impostos municipais”. Por fim, no que se refere à “facultatividade”, José Roberto Viera, convencido pelo argumento de que “...diante de um estado que não tenha estabelecido o ICMS em seu território, restaria aos demais buscar judicialmente o ressarcimento dos prejuízos, nunca se cogitando de que coubesse ao Judiciário legislar ou determinar ao estado omisso que o fizesse quanto a esse imposto", mantém-se firme na posição de entender a competência tributária, mesmo aquela que trata da instituição do ICMS, portadora da característica da facultatividade (2005c, p. 624). 


\section{SOBRE OS PRINCÍPIOS: OS PRINCÍPIOS GERAIS}

José Roberto Vieira afirma ser “...prioridade inadiável...” identificar os princípios jurídicos do sistema constitucional, na medida em que “...disso depende a possibilidade de compreensão ampla do sistema e dos seus esquemas estruturais, uma vez que eles funcionam como pressupostos inafastáveis da atividade interpretativa” (1993, p. 38, grifo do autor). E, atribui maior relevância aos princípios da República, da Federação, da Autonomia Municipal e da Isonomia das Pessoas Constitucionais “...em função das luzes que fazem incidir sobre a província tributária da nova ordem jurídica” (1990, p. 95).

\subsection{PRINCÍPIO DA FEDERAÇÃO}

Sobre o Princípio da Federação, José Roberto Vieira dedicou algumas páginas de artigo escrito no início da década de 90. Entretanto, não podemos olvidar dos debates travados por ele com Clémerson Merlin Clève, em palestras e bancas de defesa de mestrado e doutorado, e também do extenso estudo escrito por ocasião da homenagem a José Eduardo Soares de Melo, intitulado “ $O$ princípio da federação, Soares de Melo e uma obra 'Federal’!” (inédito).

O exame do Princípio da Federação mostra-se importante na medida em que, como alerta José Roberto Vieira, colabora com a concretização da República (1990, p. 103). A menção à Federação vem logo no início do texto Constitucional. Prescreve seu artigo $1^{\circ}$ que "A República Federativa do Brasil, formada pela união indissolúvel dos Estados e Municípios e do Distrito Federal, constitui-se em Estado Democrático de Direito e tem como fundamentos...”. Esse modelo foi copiado, já em 1891, do sistema constitucional estadunidense. A importância da federação é elevada a ponto de ser cláusula pétrea, integrando o núcleo duro, o cerne imodificável, da Constituição Federal. Lá está, em seu artigo 60, § 4º I, que “Não será objeto de deliberação a proposta de emenda tendente a abolir: ... a forma federativa de Estado”. O vocábulo “federação” deriva do latim “foedus, foederis”, que remete à ideia de pacto, união, associação, aliança (1990, p. 102). Lembra, naquele artigo ainda inédito, que “...não existe “a federação”, mas “as federações”. São muitas, e cada qual com traços próprios, embora diversos deles sejam comuns” (inédito).

A federação estadunidense, por exemplo, foi “...composta num movimento centrípeto, de tendência da periferia para o centro", também chamada de "Federalismo por agregação ou associação”. A federação brasileira, possui “...inclinação centrífuga, movendo-se do centro no sentido do perímetro...”, adjetivada de “federalismo por segregação ou dissociação” (inédito). 
Na visão de José Roberto Vieira, caracterizam a Federação: a repartição constitucional de competências, a participação da vontade das ordens jurídicas parciais na vontade da ordem jurídica nacional, e a possibilidade de autoconstituição (constituições locais). E, a rigidez constitucional e a existência de órgão constitucional encarregado de realizar o controle de constitucionalidade das leis, mantém a Federação (1990, p. 102 e item 2.6, inédito).

Essa cláusula pétrea é, para José Roberto Vieira, “...integrante indiscutível do coração constitucional” (1998, p. 527) e ostenta “...elevado grau de relevância jurídica...” (inédito).

Encerremos o tópico mencionando a visão de José Roberto Vieira sobre o “integrarem” ou não os municípios a Federação. Diz ele, no item 2.8 (“Município: Entidade Não Federativa”) de estudo ainda inédito: “...conquanto portadores de toda a dignidade constitucional da sua indefectível autonomia, os nossos municípios não são, indubitavelmente, entidades federativas” (inédito).

\subsection{PRINCÍPIO DA TRIPARTIÇÃO DAS FUNÇÕES}

Em lugar de "Separação ou Tripartição dos Poderes", prefere José Roberto Vieira a “Tripartição de Funções”, baseando-se nas lições de Renato Alessi e de Celso Antônio Bandeira de Mello acerca da ideia de função. Alessi define função como “...o poder concebido em relação à realização de determinado interesse”. Celso Antônio Bandeira de Mello, por sua vez, acrescenta que “...o poder dirigido ao implemento da finalidade legal destina-se ao resguardo do interesse de outrem” (1990, p. 100).

José Roberto Vieira inicia o exame citando a doutrina acerca da separação das funções de Charles-Louis de Secondat, Barão de La Brède e de Montesquieu. N’O espírito das leis há passagem que traduz à perfeição o que a teorização visa a evitar:

Quando na mesma pessoa ou no mesmo corpo de magistratura, o poder legislativo está reunido ao poder executivo, não existe liberdade; porque se pode temer que o mesmo monarca ou o mesmo senado crie leis tirânicas para executá-las tiranicamente. Tampouco existe liberdade se o poder de julgar não for separado do poder legislativo e do poder executivo. Se estivesse unido ao poder legislativo, o poder sobre a vida e a liberdade dos cidadãos seria arbitrário, pois o juiz seria legislador. Se estivesse unido ao poder executivo, o juiz poderia ter a força de um opressor (MONTESQUIEU, 1996, p. 168).

José Roberto Vieira explica que "A teoria parte da existência de três funções estatais: a legislativa (produção do ato geral), a executiva (produção do ato especial) e a judiciária (resolução de controvérsias); funções que no estado Absoluto, concentravam-se nas mãos do soberano, possibilitando a tirania”. Diz mais: que Montesquieu, no mencionado livro, “...concebeu um sistema 
em que tais funções são entregues a órgãos distintos $\boldsymbol{e}$ autônomos, que, no refrear e suster recíprocos, configuram aquele sistema de 'freios e contrapesos'...” (1990, p. 100, grifo do autor).

Entretanto, José Roberto Vieira não se limita a enunciar a teorização de Montesquieu. Menciona também a de Hans Kelsen, que identificava duas funções do Estado: a criação do direito (Legislativo) e a aplicação do direito (Executivo ou Administração e Judiciário); como também faz referência à doutrina de Oswaldo Aranha Bandeira de Mello, que apresenta a Função Administrativa, que compreende a ação legislativa e a ação executiva, e a Função Jurisdicional, que compreende a ação judicial (1990, p. 100).

\subsection{PRINCÍPIO DA REPÚBLICA}

José Roberto Vieira é enfático ao afirmar, concordando com Geraldo Ataliba, que o Princípio da República é o “...mais importante e decisivo do nosso Direito Público” (1990, p. 101). Entretanto, "Em termos republicanos e democráticos encontramo-nos também nós, brasileiros, em tenra idade" (2002b, p. 98). Segundo ele, são características desse regime de governo, a República: “a representatividade, decorrente da eletividade, a transitoriedade e a responsabilidade” (1990, p. 101, grifo do autor). A mais relevante dessas características, em sua visão, é a representatividade, na medida em que “...as autoridades são meros administradores da coisa pública - res publica - a título de mandatários do povo, que detêm a sua propriedade”. Em razão disso a ideia de mandato seria a "Pedra de Toque" da República (1990, p. 101). É bem verdade que parte da doutrina questionou o integrar a República o rol de cláusulas pétreas. José Roberto Vieira é enfático no alocála no núcleo imutável da Constituição².

Poderíamos indagar se seria o conceito de República um “óbvio ululante”? Principalmente em razão de estar “...indubitavelmente, entre alguns dos mais comuns, correntes, batidos, triviais do [...] Direito Público” (2006a, p. 187, grifo do autor). Decididamente não, ensina-nos José Roberto Vieira ${ }^{3}$.

\footnotetext{
2 "Conquanto a doutrina constitucional brasileira, após o advento do texto de 1988, numa lamentável tendência literal, incline-se no sentido de que a República não mais constitui cláusula intocável, é evidente que, vencida, em 21 de abril de 1993, a possibilidade de revisão constitucional a respeito (artigo $2^{\circ}$ do Ato das Disposições Constitucionais Transitórias), a sua idéia nuclear de representação (voto direto, secreto e universal - artigo 60, $\$ 4^{\circ}$, II) segue presente, assim como a de temporariedade (voto periódico - artigo 60, $\S 4^{\circ}$, II), e até mesmo a de igualdade, para aqueles que a entendem integrante da noção republicana (entre os direitos individuais - artigo 60, $\$ 4^{\circ}$, IV). Para Carmem Lúcia Antunes Rocha, cuja posição se nos afigura sensata, entre a promulgação constitucional e o plebiscito de 1993, a república não foi cláusula pétrea, pela possibilidade de sua modificação pela via revisional, após o que, recobrou sua condição de imodificável, como limite material implícito” (2004, p. 180).

3 "Se no momento primeiro deste texto, considerando que República e Democracia são conceitos tão assiduamente versados pela doutrina publicista, cogitamos de talvez encará-lo como óbvios, embora pondo em dúvida tal condição,
} 


\subsection{PRINCÍPIO DA AUTONOMIA MUNICIPAL}

O Princípio da Autonomia Municipal, de acordo com José Roberto Vieira, já era estabelecido no Brasil Colônia, “...antes de qualquer cogitação de autonomia política para os EstadosMembros”. Esse princípio é expressamente previsto no artigo 34, VII, “c”, do texto constitucional. Lembremos, também, que os municípios, apesar de não integrarem o Pacto Federativo, têm “...capacidade para legislar sobre negócios seus por autoridades próprias” (1990, p. 103 e item 2.7, inédito).

\subsection{PRINCÍPIO DA SEGURANÇA JURÍDICA}

Ensinou-nos José Roberto Vieira que “A noção de segurança jurídica é, via de regra, identificada com a de certeza do direito", abrangendo, entretanto, mais do que ela, na medida em que inclui “...idéia de previsibilidade da ação estatal, para afastar dos indivíduos as surpresas que repugnam ao nosso sistema jurídico” (1990, p. 99). De fato, “Do latim 'securus’ (livre de perigo), ou, com maior detalhe, da conjunção de vocábulos latinos 'sine + cura' (sem preocupações), segurança significa isenção de cuidados” (2005d, p. 319, grifo do autor).

No subsistema constitucional tributário, José Roberto Vieira identifica alguns princípios que realizam a segurança jurídica. São eles: o Princípio da Estrita Legalidade, o Princípio da Irretroatividade (artigo 5, XXXVI e artigo 150, III, “a”), o Princípio da Anterioridade (artigo 150, III, “b”) e o Princípio da Universalidade da Jurisdição (artigo 5º XXXV) (1990, p. 99, 1997, p. 98). Desses, dois integram, ao lado do Princípio da Igualdade e da Capacidade Contributiva, o chamado Estatuto do Contribuinte: o Princípio da Anterioridade e o Princípio da Igualdade (2011, p. 364). Quanto ao Princípio da Anterioridade, lembremos, o seu sentido seria o de “...evitar surpreender os contribuintes” (1997, p. 97). Esse Princípio protela “...a eficácia das leis que instituem ou majoram tributos para o exercício subsequente” (2004, p. 199, 2005d, p. 353).

\footnotetext{
não nos incomoda ao fim de admitir, só para argumentar, essa obviedade; desde que não se lhe adjetive de 'ululante', compondo a imagem rodrigueana completa. E isso porque, se no patamar exclusivamente da teoria pode-se tolerar a eventual conotação de evidência dessas noções, tal não se dá, com clareza resplandecente e fulgurante, no nível da prática, pois o modo pelo qual elas se concretizam na experiência dos estados contemporâneos, especialmente na nossa particular, fica a incomensuráveis distâncias da elevada altitude de suas especulações abstratas. Afastamento teóricoprático que, num giro inverso, constitui, este sim, inevitável óbvio, a reclamar urgente acusação. Em outras palavras, mesmo que não sejam óbvios os conceitos, e muito menos ululantes, de inegável obviedade, até mesmo ululante, é o desleixo na sua concretização, a negligência na sua materialização, a escassez da sua execução, a ausência de sua realização" (2006a, p. 187, grifo do autor).
} 
Ao Princípio da Legalidade, por sua superior importância, dedicaremos tópico próprio. No palco dos princípios garantidores da segurança, José Roberto Vieira é direto: “Não se duvida de que, nesse palco, o papel principal é sempre reservado à Legalidade” (2005d, p. 324).

O Princípio da Irretroatividade, por sua vez, é consagrado de forma genérica (artigo 5², XXXVI) e, em matéria tributária, o é de forma específica (no artigo 150, III, “a”), ao vedar “...a exigência de tributos em relação a fatos ocorridos antes da vigência da lei que os houver instituído ou aumentado...” (1997, p. 97).

\subsection{PRINCÍPIO DA LEGALIDADE}

Analisando a doutrina estrangeira, José Roberto Vieira faz interessante retomada histórica do Princípio da Legalidade, frisando que antes mesmo da promulgação da Magna Charta Libertatum, às margens do rio Tâmisa, pelo rei João Sem Terra, havia documentos anteriores “...em que a nota comum é o consentimento dos destinatários de certos tributos” (1999, p. 103-114, 2014a, p. 945957; 2015, p. 171-178, grifo do autor). Não estenderemos o exame histórico do Princípio da Legalidade, pois esse não é o escopo da presente homenagem. Entretanto, frisemos que “Não divergem os historiadores, juristas e cientistas políticos no reconhecimento de que esse cânone fundamental tem sua origem intimamente conectada ao consentimento dos tributos” (1999, p. 101, grifo do autor).

Quanto ao Princípio da Legalidade - que é “...uma presença praticamente inevitável nos estados modernos...” (1999, p. 101), José Roberto Vieira examina-o, num primeiro momento, a partir da teorização do administrativista português chamado André Gonçalves Pereira, que trata de uma concepção restritiva e de uma concepção ampliativa do Princípio da Legalidade. A primeira (Princípio da Preeminência da Lei), já ultrapassada, traz a ideia de "não infringir a lei”, ou seja, estabelece uma “...relação de não contrariedade ou de compatibilidade (agir de modo não contrário ou compatível com a lei, que só fixa limites - o que não é proibido é permitido), numa noção mínima de legalidade”. A segunda (Princípio da Reserva de Lei), por sua vez, vem acompanhada da ideia de “agir nos termos da lei”, ou seja, é identificada com uma “...relação de conformidade (agir conforme a lei, que fixa limites e permissões expressas - o que não é permitido é proibido), numa noção máxima de legalidade” (1990, p. 96, 2002b, p. 104) . Mas, e no Brasil? Não hesita José Roberto Vieira em

\footnotetext{
${ }^{4}$ Aqui, é importante mencionar que o Princípio da Legalidade abrange o Princípio da Constitucionalidade. Eis as palavras de José Roberto Vieira: “...não faz sentido cogitar de uma legalidade que exclua de consideração o texto constitucional, a 'lei das leis', desde que a legalidade consiste, nada mais, nada menos, e na sua porção mais respeitável e veneranda, em autêntica constitucionalidade. De outro ângulo, é irrecusável a afirmativa de que uma inconstitucionalidade constitui
} 
...proclamar o Princípio da Legalidade como uma relação de conformidade com a lei em sentido formal, ato oriundo do órgão que detém competência constitucional para legislar e revestido da forma estabelecida para as leis, e não só em sentido material, regra de comportamento genérica e coativa (1990, p. 96, grifo do autor).

É importante, também, fazermos menção, nas palavras de José Roberto Vieira, à dupla significação da Legalidade Tributária. Diz ele:

Enquanto a legalidade tributária, no sentido formal, corresponde à exigência de lei como veículo, ato oriundo do legislativo; a legalidade tributária, na acepção material, equivale exatamente, em termos de conteúdo, à tipicidade cerrada, à necessidade de que todos os dados da norma de incidência sejam especificados pela lei. E que o sejam com elevado rigor e precisão (2016b, p. 179-180).

Lembremos, com José Roberto Vieira, que "Mais do que a vontade estatal, a lei é a manifestação suprema da vontade popular, vontade de cada cidadão, por intermédio da representação política, constituindo à quase perfeição o instrumento da soberania popular” (1990, p. 97, 1991, p. 147, grifo do autor). É por isso que ele mesmo afirma que é a legalidade a “...estação primeira onde deságua incontida a representatividade republicano-democrática...” (2002b, p. 103). É pela “...estrada...” da legalidade que o “...Direito ganha a dimensão da reflexividade e o 'homo juridicus’ salta das planícies da 'imposição’ para as altitudes da 'auto-imposição”’ (2004, p. 186). Na atual Constituição, este princípio é estabelecido tanto em sua acepção genérica, no artigo 5, II, quanto em sua disposição tributária específica, no artigo 150, I, que “...possibilita e realiza a idéia de autotributação" (2002b, p. 108). Aqui, há lugar para o exame do significado de "instituir tributo". De acordo com José Roberto Vieira, é legislando que se institui o tributo. Dessa forma, a competência tributária é, antes de tudo, competência legislativa. Termina por concluir que instituir tributo é “...editar, com suas minúcias todas, a norma jurídica de incidência” (2014a, p. 941, grifo do autor). Citando as constituições pretéritas, assim se manifesta José Roberto Vieira sobre a Legalidade Tributária no Direito Brasileiro:

\begin{abstract}
O legislador constitucional, com o socorro do Código Tributário, construiu a monumental cidadela da Legalidade Tributária. Sobre as bases e os alicerces republicanos e sobre as fundações e os esteios democráticos, erigiu um castelo formidável para a legalidade, que se nos afigura, à primeira vista, invulnerável e inexpugnável. E o fez de forma gradual e paulatina, ao longo dos séculos, no compasso vagaroso e paciente dos nossos diversos diplomas constitucionais, desde o documento imperial de 1824, os autoritários de 1937 e de 1969, e os republicanos-democráticos de 1891, de 1934, de 1946, de 1967 e de 1988. Não é à toa que sua condição de direito fundamental (artigo $5^{\circ}$, II) e de garantia do contribuinte (artigo 150, I), protege-o de qualquer investida que lhe guarde tendência contrária (artigo 60, $\left.\S 4^{\circ}, \mathrm{IV}\right)$, como verdadeira cláusula “pétrea”, da mais pura e inatingível pedra. Todavia, uma
\end{abstract}

uma ilegalidade qualificada. Logo, o Princípio da Legalidade inclui e abarca o Princípio da Constitucionalidade, este, exatamente, como a sua parcela de maior fidalguia, como a sua fatia de maior nobreza, como quinhão de excelência da Legalidade” (2014b, p. 604-605, grifo do autor). 
segunda e mais atenta mirada, como a que lhe acabamos de dirigir, neste trabalho, revela que essa fortificação, longe de invencível, exibe debilidades; longe de inconquistável, ostenta fragilidades (2016b, p. 190).

Examinando as prescrições do artigo 153, § $1^{\circ}$, da Constituição Federal, ressalta José Roberto Vieira que não se trata de exceção à legalidade. No máximo, uma exceção aparente, “...porque a licença do Código Maior para o executivo não é ampla e irrestrita, mas estritamente subordinada às demarcações que a lei impuser” (1998, p. 555, 2006b, p. 194-195). Em texto publicado em 2014, José Roberto Vieira, em capítulo intitulado “Meras Atenuações, Nenhuma Exceção”, explica que haverá exceção à legalidade genérica apenas em um caso: o da edição de medidas provisórias, previstas no artigo 62, da Constituição Federal, ato normativo de governo, que com a lei não se identifica. Entretanto, é enfático ao afirmar não existirem exceções ao Princípio da Legalidade Tributária. São palavras dele, no texto terminado em 30 de abril de 2014, Dia de São Pio $\mathrm{V}$ :

Eis que a única disposição constitucional que reduz a rigidez e a intransigência da Legalidade Tributária, no que diz respeito à definição legal dos dados estruturais da norma de incidência tributária (artigo 153, § $1^{\circ}$ ), não chega sequer a excepcioná-la, correspondendo apenas a simples abrandamentos, constituindo tão só meras atenuações do princípio (2014a, p. 957-961, grifo do autor).

Encontramos verdadeira exceção à Legalidade, por exemplo, nas prescrições do artigo 177, § 4", I, "b”, da Constituição Federal, incluído pelo artigo $3^{\circ}$ da Emenda Constitucional n. 33, de 11 de dezembro de 2001 - de duvidosa constitucionalidade por afronta ao artigo 60, § $4^{\circ}$, IV -, o qual prescreve que

A lei que instituir contribuição de intervenção no domínio econômico relativa ás atividades de importação ou comercialização de petróleo e seus derivados, gás natural e seus derivados e álcool combustível deverá atender aos seguintes requisitos: I - a alíquota da contribuição poderá ser: [...] b) reduzida e restabelecida por ato do Poder Executivo, não se lhe aplicando o disposto no art. 150, III, $b$.

Ao tratar de tema diretamente ligado à Legalidade, em 1997, José Roberto Vieira, em coautoria com Diego Marín-Barnuevo Fabo, frisou que, no Brasil, a “...Medida Provisória não pode ser utilizada para instituir ou majorar tributos, perante disposição constitucional que exige lei para tais providências...” (1997, p. 97). Anos mais tarde, em 2004, entretanto, alertou:

No estado brasileiro contemporâneo, o doce sabor cívico da Legalidade em geral, especificamente da Legalidade Tributária, oculta disfarçadamente o gosto amargo da Medida Provisória. E os cidadãos brasileiros, na inocência de sua infância republicana e democrática, celebram a vida pública com taças reluzentes e sedutoras, porque com suas bordas embebidas pela delícia açucarada do mel da legalidade, um alimento fundamental, e, no mais das vezes, restam iludidos pela máscara amena que esconde insidiosa a substância perigosa da medida provisória; em nosso caso clínico, uma droga que, pelo uso excessivo e descontrolado, 
provocou vício e dependência, convertendo-se em autêntico veneno! (2004, p. 175, grifo do autor).

Iniciemos, então, o trato dessa “...substância potencialmente tóxica [...] que se esconde sob a doçura da Legalidade Genérica e Tributária”, que são as Medidas Provisórias (2004, p. 190), para as quais José Roberto Vieira dedicou sua tese de doutorado (1999).

As Medidas Provisórias, previstas no artigo 62 da Constituição Federal, são, de acordo com José Roberto Vieira, “ato normativo primário de governo, dotado apenas de força de lei” (2004, p. 196). É interessante refazer o caminho argumentativo trilhado por José Roberto Vieira para alcançar tal conclusão. Num primeiro momento, ele justifica sua discordância com aqueles que nela veem um “ato legislativo”. Ele é enfático ao afirmar que “Medida Provisória não é lei”. Eis as razões: i) se medida provisória fosse lei, não lhe seria necessária a outorga expressa, por parte do legislador constitucional, de força de lei; ii) se medida provisória fosse lei, não seria necessário que o Congresso Nacional a convertesse em lei. Afinal, “...é evidente que só se converte, se transforma, se transmuda em lei aquilo que lei não era”; iii) se medida provisória fosse lei, não teria apenas “força de lei”; iv) "O fato de que se lhe concede, transitoriamente, força de lei, não significa, de modo algum, que ela tenha valor de lei (natureza)” (2004, p. 192-193)

José Roberto Vieira não se enquadra no grupo daqueles que afastam a possibilidade de utilização das Medidas Provisórias no campo da tributação. Apesar de colocar-se “...ao lado daqueles que inadmitem o instrumento governamental provisório para a instituição e a majoração de tributos” - em razão da afronta à Legalidade e à Anterioridade -, admite sua utilização em determinados casos que “...não acarretam risco para a liberdade e a propriedade...” (2004, p. 198-199). Um desses casos é a elevação das alíquotas dos impostos previstos no artigo 153, § $1^{\circ}$, da Constituição Federal. O Poder Executivo, além do Decreto, poderá valer-se da Medida Provisória6.

\footnotetext{
${ }^{5}$ E conclui: “Em síntese, temos a lei, caracterizada pela normalidade, permanência, consistência, eficácia pretérita preservada e independência de pressupostos; a medida provisória, excepcional, efêmera, precária, suscetível de perda da eficácia desde sempre, e restrita às hipóteses de urgência e relevância” (2004, p. 194).

6 “Quanto à possibilidade da providência por Medida Provisória, embora o Texto Supremo tenha-lhe destinado instrumento próprio e de menor rigor (decreto), quando da urgência e relevância, não cremos poder recusar ao executivo a perspectiva de chamar o legislativo para dividir as responsabilidades das decisões, em homenagem aos Princípios da Legalidade, da Tripartição das Funções e da própria República” (1993, p. 130, grifo do autor). Em outro texto, de 2004, complementa: "É evidente a improbabilidade da hipótese, pois se pode o Presidente da República tomar a medida por decreto dificilmente fá-lo-ia pelo caminho mais árduo da medida provisória. É uma possibilidade, contudo, e não encontramos razão alguma para rechaçá-la. Se unipessoalmente poderia o presidente fazê-lo, e resolve convidar para a decisão os representantes do povo e dos estados, prestigiando os princípios mencionados (Legalidade, República e Tripartição das Funções), mais o da Democracia, acrescentaríamos, não vemos fundamento para negar-lhe isso, senão, ao contrário, só fundamento para encômios. [...] Trata-se de pura e primária aplicação de argumento 'a fortiori', do tipo 'a maiori ad minus', expresso, como lembra Georges Kalinowski, na fórmula dos antigos 'Qui potest plus, potest minus’, que, obviamente, nem sempre é de utilização possível, como explica Chaïm Perelman, mas nesse caso irrecusável” (2004, p. 202-203, grifo do autor).
} 
A disciplina constitucional das Medidas Provisórias sofreu sensível modificação, por meio da Emenda Constitucional n. 32, de 11 de setembro de 2001, uma emenda "terrorista” (2005a, p. 713). Essa Emenda, que foi adjetivada de "tímida e pusilânime" e de "indulgente" e "condescendente" para com o Poder Executivo; e que foi responsabilizada por trazer novos estorvos para o instituto da Medida Provisória, decorrente dos quais se experimentam “desencanto” e "desalento”, trouxe, na visão de José Roberto Vieira, aspectos positivos e aspectos negativos, estes em maior número que aqueles, de modo que é possível dizer que “...é portadora de algum mel e de muito veneno” (2004, p. 212) ${ }^{7}$. Ele é enfático ao afirmar que

...com tal emenda recebemos, ao invés da solução normativa desejada, novos surtos de problemas normativos; ao invés do remédio constitucional almejado, novos tremores de doença constitucional; ao invés da cura cívica cobiçada, novas crises de moléstia cívica; ao invés do alívio cidadão ansiado, novas convulsões de enfermidade cidadã (2004, p. 206207).

Quanto aos aspectos positivos, são eles: i) as restrições materiais negativas, com o estabelecimento de assuntos que não poderão ser disciplinados por meio de Medida Provisória; ii) a limitação à possibilidade de reedição (prorrogação) a uma única, na mesma sessão legislativa; iii) a determinação expressa da apreciação parlamentar, prévia ao exame de mérito, dos seus pressupostos constitucionais; iv) aplicação às Medidas Provisórias do regime de urgência aplicável aos projetos de lei de iniciativa do Presidente da República; e v) a inclusão automática das Medidas Provisórias em vigor na pauta das convocações extraordinárias do Congresso Nacional (2004, p. 207-208). Quanto aos aspectos negativos, José Roberto Vieira classifica-os em “de baixa ou média negatividade” e em “de alta ou altíssima negatividade”. São de baixa ou média negatividade: i) o aumento do prazo de excepcionalidade de trinta para sessenta dias; ii) a suspensão da contagem do prazo durante o recesso do Congresso Nacional; iii) o fim da convocação extraordinária do Congresso Nacional, em cinco dias, para apreciar medida provisória editada durante o seu recesso; iv) a admissão expressa da possibilidade de revogação de uma medida provisória por outra (2004, p. 208-209). Os aspectos de alta ou altíssima negatividade são os seguintes: i) o considerar o rol de limitações materiais como

\footnotetext{
${ }^{7}$ É interessante lembrarmos que essa emenda foi tema de artigo específico, já clássico. Em 2005, escreveu José Roberto Vieira, logo após tecer comentários a respeito de Manuel Maria Barbosa du Bocage: "E por que essas considerações literárias e poéticas na introdução de um trabalho jurídico acerca das medidas provisórias?! [...] Há duas razões mais específicas, porém. A primeira relaciona-se com um curioso e interessante episódio da vida de BOCAGE que nos conta DEONÍSIO DA SILVA. Um aspirante a poeta entregou-lhe um soneto que escrevera, pedindo-lhe a apreciação valiosa, e mais, que assinalasse com cruzes os erros eventualmente detectados. Deve ter sido grande a sua surpresa inicial quando, após a leitura, BOCAGE devolveu-lhe o poema sem qualquer marca. Mas deve ter sido maior ainda a frustração, quando ouviu a explicação do poeta: seriam tantas cruzes que a emenda ficaria pior do que o soneto! Não logramos imaginar descrição melhor para o ocorrido com a emenda constitucional que tentou corrigir problemas do desenho normativo da medida provisória, como certamente restará claro das reflexões que nos encontramos a ponto de empreender. Tanto é verdade que adotamos a expressão no título deste trabalho” (2005a, p. 694-695, grifo do autor).
} 
taxativo; ii) a admissão expressa de uma reedição (prorrogação) da Medida Provisória na mesma sessão legislativa; iii) a possibilidade de reedição de Medida Provisória tácita ou expressamente rejeitada, na sessão legislativa seguinte; iv) o estabelecimento da perda da eficácia a partir da rejeição - e não a partir da edição -, nos casos de não edição do decreto legislativo competente, em sessenta dias, para disciplinar as relações jurídicas decorrentes da Medida Provisória não convertida em lei; v) a extinção, para o futuro, do limite imposto às Medidas Provisórias que versassem temas objeto de emendas, a partir de 1995; e vi) a transformação de todas as Medidas Provisórias editadas e vigentes até então, em Medidas Permanentes, até a deliberação posterior do Congresso Nacional ou até a sua revogação expressa (2004, p. 208-210).

Especificamente, em matéria tributária, mesmo reconhecendo José Roberto Vieira alguma positividade, em razão da “...submissão da instituição ou majoração de impostos à anterioridade não em relação à medida provisória que tomar a providência, mas em relação à lei em que se converter a medida provisória...”, ele é enfático ao apontar a suprema negatividade

...que raia pelo âmbito da insensatez e do disparate constitucional, da admissão de medida provisória para instituição e majoração de impostos, de um lado [...]; e de outro, do esvaziamento do pressuposto material da urgência de tal medida provisória, ao submetê-la à anterioridade da lei em que vier a se converter... (2004, p. 210-211).

Passemos, então, à análise dos pressupostos constitucionais materiais das Medidas Provisórias. O primeiro deles, a relevância, é relacional. Isso porque a “...possibilidade de adoção de uma medida provisória estaria, pois, em relação direta com a impossibilidade do parlamento tomar as providências nela contidas em tempo hábil para fazê-las eficazes, em virtude dos procedimentos e prazos mínimos que são inerentes à disciplina do agir parlamentar” (2005d, p. 330). É necessário, então, buscar, no próprio Texto Constitucional, qual é esse prazo. Ou melhor, qual é o prazo de tramitação de projetos de lei de iniciativa do Presidente da República em regime de urgência? A resposta é cem dias: “urgente é a medida provisória que não possa aguardar o curso normal, ou com pedido de urgência - 90 dias, normalmente, ou 100, no caso de emendas - de projetos de lei apresentado pelo Presidente da República; caso contrário, não o será, tornando-se assim inadmissível” (2005d, p. 331).

\footnotetext{
${ }^{8}$ Em outro trabalho, José Roberto Vieira mencionava esse prazo como sendo de 45 (quarenta e cinco) dias (2005a, p 703). Eis a explicação de José Roberto Vieira para a mudança de entendimento: "Em face do dispositivo constitucional pertinente, contudo - 'Se... a Câmara dos Deputados e o Senado Federal não se manifestarem, cada qual sucessivamente, em até quarenta e cinco dias, sobrestar-se-ão todas as demais deliberações... até que se ultime a votação' (artigo 64, § $2^{\circ}$, na redação da Emenda Constitucional ${ }^{\circ}$ 32, de 11 de setembro de 2001) - parece-nos, hoje, que o esforço sintático de uma interpretação não mais do que literal é bastante e suficiente. Colocada a cláusula 'cada qual' antes do prazo de 45 dias, tem o sentido de outorgá-lo respectiva e separadamente a cada uma das duas casas do parlamento, num total conjunto de 90 dias. Dissesse porventura o legislador constitucional que a Câmara e o Senado se deveriam manifestar, 'em até
} 
Se, no que se refere à urgência, há precisão, lamentavelmente não podemos dizer o mesmo quanto à relevância, que é um daqueles “conceitos jurídicos indeterminados”. Deve-se buscar seu conceito por meio de interpretação contextual constitucional. Em razão disso, "Sempre $e$ inevitavelmente em função do interesse público, e à luz da escala de relevância que decorre dos valores constitucionalmente consagrados nos seus princípios, é que o Presidente da República poderá fazer uso do instrumento normativo provisório”. Deverá fazê-lo motivadamente, frise-se (2005d, p. 336-342).

Por fim, conclui serem duas as barreiras à utilização das Medidas Provisórias para a instituição e a majoração de tributos: a Legalidade Tributária e a Anterioridade Tributária (2005a, p. 710).

Há, ainda, outro assunto do qual devemos tratar: a impossibilidade das delegações legislativas para a instituição de tributos. José Roberto Vieira adverte que o legislador constitucional, por meio do artigo 25 do Ato das Disposições Constitucionais Transitórias, “...evidenciou uma disposição genérica em desfavor das delegações legislativas...”, principalmente quando estabeleceu a revogação dos dispositivos que atribuam ou deleguem a órgão do Poder Executivo competência assinalada pela Constituição ao Congresso Nacional, principalmente no que se refere à "ação normativa”. De fato, tem razão ao concluir que "Na seara dos tributos, então, muito escasso seria o efeito da Legalidade Tributária, requerendo lei para a criação e o aumento de tributos, se possível fosse, ao legislativo, delegar essas funções de alto impacto tributário ao Executivo” (2016b, p. 181182). Caso assim o fizesse, o Poder Legislativo trairia o povo ${ }^{9}$. Antes fosse essa a única traição do Legislativo ao povo brasileiro! Sabemos que suas traições diárias são muito mais escandalosas.

Tanto na produção quanto na aplicação do direito tributário positivo brasileiro, parece-nos, vivemos o pesadelo da lei da selva! ${ }^{10} \mathrm{E}$, nesse pesadelo, as portas de nossa fortaleza - que ostenta

\footnotetext{
quarenta e cinco dias, cada qual sucessivamente’, e então, a localização da referência ao prazo antecedendo a cláusula 'cada qual sucessivamente', prevaleceria para o conjunto de ambas as casas, restringindo-se o 'cada qual' apenas à condição sucessiva e não simultânea da manifestação de cada uma delas. Não é assim, todavia, e por isso passamos a ver a questão dessa forma” (2005d, p. 333-334).

9 “Com efeito, desde que a legalidade, com amparo nas noções de República e de Democracia, sempre foi semanticamente carregada, ao longo da história, com a expressividade da representação popular, se o parlamento, detentor original do ofício de legislar, entrega-o graciosamente ao chefe do executivo, escolhido pelo povo para um iter público bem diverso, quedará o povo atraiçoado por um legislativo desleal e infiel à sua missão política e constitucional” (2016b, p. 183).

${ }^{10}$ Diz José Roberto Vieira: "Se vigiamos o cumprimento dos comandos que realizam a representatividade republicanodemocrática. Mais: se velamos pelo respeito às regras que implementam a efetiva participação popular nas decisões legislativas. Mais ainda: se denunciamos o menoscabo pelas normas que prestigiam os valores fundamentais da liberdade e da igualdade, inclusive e especialmente quando aquém do simplesmente formal. Por exemplo, em matéria tributária, se esclarecemos e apontamos os mandamentos que menosprezam o estreito compromisso do ordenamento com o princípio da capacidade contributiva, desdenhando, por decorrência, o magno princípio da igualdade tributária; como os da legislação do ICMS e do IPI, que agridem a seletividade, ou os da legislação do IPTU, que insultam a progressividade. Se nossas respostas a esses e tantos outros semelhantes 'se' são indecisas, vacilantes, titubeantes,
} 
“...aparência firme e robusta de um forte da mais rija e tesa rocha...” - da Legalidade, lamentavelmente, são de papel (2016b, p. 190-191).

\title{
4.7 PRINCÍPIO DA IGUALDADE
}

O Princípio da Igualdade integra, “...sem chance de contestação...”, o Estatuto do Contribuinte (VIEIRA, 2012, p. 173). Ao examinar o caput do artigo $5^{\circ}$ da Constituição Federal, José Roberto Vieira afirma que o “Todos são iguais perante a lei, sem distinção de qualquer natureza...”, é mandamento que “...não se limita a igualar os indivíduos em face das leis...”, estabelecendo, também, a “...igualdade na lei” (1990, p. 97, grifo do autor).

Lembra, ainda, José Roberto Vieira que a “...regra da igualdade não é absoluta”. Ele atribui a Aristóteles a ideia de "igualdade relativa”, que remonta ao "Ética a Nicômaco". Em "Oração aos Moços” - texto dirigido aos formandos da Faculdade de Direito do Largo São Francisco, de 1921 Rui Barbosa declama, na visão de José Roberto Vieira, “...o enunciado de maior beleza...” (1990, p. 98):

\begin{abstract}
A regra da igualdade não consiste senão em quinhoar desigualmente aos desiguais, na medida em que se desigualam. Nesta desigualdade social, proporcionada à desigualdade natural, é que se acha a verdadeira lei da igualdade [...] Tratar com desigualdade a iguais, ou a desiguais com igualdade, seria desigualdade flagrante, e não igualdade real (2003, p. 26).
\end{abstract}

É bem verdade que José Roberto Vieira alerta que essa “...construção multissecular e bela ainda não desnuda toda a latitude...” do Princípio da Igualdade. Diz, ainda, que “...sabemos [...] hoje, da indisfarçável insuficiência dessa concepção...” (2012, p. 177, grifo do autor). Seria necessário enfrentar a questão lançada por Celso Antônio Bandeira de Mello: “Quem são os iguais e quem são os desiguais?” (VIEIRA, 1990, p. 98). Segundo José Roberto Vieira, é a Celso Antônio Bandeira de Mello a quem devemos

...o esforço primeiro, entre nós, de aprofundamento da investigação, nesse campo, identificando as condições de concretização do princípio, mediante o exame; do fator de discriminação; da correlação lógica entre esse fator e o tratamento jurídico estabelecido [...] e da consonância entre essa correlação e os valores constitucionais.

\footnotetext{
hesitantes, então não só não nos encontramos imbuídos de autêntico espírito republicano-democrático como, pelo contrário, acabamos nos voltando para a direção oposta e elegendo como caminho e destino o domínio da Lei da Selva, a barbárie e a animalidade pré-histórica. Aí o pesadelo! Se, em contrapartida, nossas respostas a esses e outros 'se' similares são firmes, decididas, determinadas, resolutas, então, ademais de revelarmos consciência republicana $e$ democrática, mantemos o bom rumo, escolhendo como itinerários e porto de chegada o âmbito da legalidade, a civilização e a humanidade de um porvir iluminado. Aí o sonho!” (2002b, p. 108).
} 
Lembra, entretanto, que Humberto Ávila prefere “compatibilidade com a finalidade” (2012, p. 177).

\subsection{PRINCÍPIO DA CAPACIDADE CONTRIBUTIVA}

O Princípio da Capacidade Contributiva, hoje expressamente previsto no artigo 145, § $1^{\circ}$, da Constituição Federal, poderia continuar implícito. Isso porque, inegavelmente, como afirma José Roberto Vieira, é “...corolário do Princípio da Igualdade em matéria tributária” (2012, p. 177-178, grifo do autor). Lembremos que “...o fundamento da Capacidade Contributiva se encontra no Princípio da Igualdade” (2013a, p. 22). Ou, ainda, que o “...Princípio da Igualdade [...] se exprime, em matéria tributária, pelo dever de pagar os tributos conforme a Capacidade Contributiva de cada um...” (2008a, p. 510, grifo do autor). Alguns poderiam criticar o conteúdo do mencionado $\S 1^{\circ}$, em razão da expressão “capacidade econômica”, nele contida. As críticas não procedem, entretanto; lembremos, como José Roberto Vieira, que “...a expressão inteira - 'capacidade econômica do contribuinte' - afasta as equivocidades, desde que indica, nitidamente, aquele cuja riqueza disponível é qualificada, tornando-o apto à sujeição passiva de uma obrigação tributária, na condição de 'contribuinte”' (2012, p. 180).

Apesar de sua “inerente indeterminabilidade”, para alcançarmos uma “noção razoável” do Princípio da Capacidade Contributiva - alerta José Roberto Vieira - não é necessário “...acompanhar toda a [sua] evolução histórico-conceptual...” (2012, p. 179-180). Em busca dessa noção, é necessário diferençarmos “capacidade contributiva” de “capacidade econômica” e de “capacidade financeira”. E, se acompanharmos José Roberto Vieira, andaremos bem. Ao investigar essa “noção razoável”, escreve:

\footnotetext{
Não se trata, pois, da simples disposição de riqueza, que indicaria mera capacidade econômica, mas do dispor de uma riqueza suficiente para a submissão ao tributo, excedente, pois, da riqueza bastante para apenas atender ao mínimo necessário para uma vida digna, satisfazendo, assim, mais do que tão só as necessidades vitais básicas do cidadão (Constituição, art. $7^{\circ}, \mathrm{IV}$ ), condição essa que, então, sim, apontaria para uma genuína capacidade de contribuir para a sobrevivência do Estado; ideia diversa, ainda, da de capacidade financeira, esta voltada para a noção de liquidez (2012, p. 632, grifo do autor).
}

Realizada a primeira distinção, para identificar a capacidade contributiva como aquilo que supera o mínimo existencial, é imprescindível apontarmos para outra distinção clássica, realizada pela doutrina, entre "Capacidade contributiva absoluta ou objetiva” e “Capacidade contributiva relativa ou subjetiva”. Quanto à “capacidade contributiva absoluta ou objetiva”, entende José Roberto Vieira que 
...cabe ao legislador selecionar, para a hipótese de incidência das normas tributárias, fatos que sejam reveladores de capacidade contributiva [...] ou, em outras palavras, fatos que constituam sinais que permitam estabelecer a presunção de existência dessa capacidade aspecto que desempenha a função de pressuposto ou fundamento jurídico do imposto.

Essa espécie de capacidade contributiva está ligada à hipótese de incidência tributária (2012, p. 180-181, 2013a, p. 25, 2014b, p. 633-634). Ao tratar do segundo caso, afirma José Roberto Vieira que

...cabe estabelecer a contribuição à medida das possibilidades econômicas de determinado sujeito passivo, adequando o quantum do tributo ao porte econômico do fato ocorrido e adequando-o às circunstâncias pessoais do cidadão; aspecto que cumpre a função de critério de graduação do tributo e de fixação dos seus limites.

Essa espécie de capacidade contributiva é atinente ao consequente da norma tributária (2012, p. 181, 2013a, p. 25, 2014b, p. 633-634). Entretanto, essas noções não estavam bem delimitadas. O próprio José Roberto Vieira reconhece, ao afirmar, mencionando trabalhos dele, que “...tal distinção foi referida de um modo um tanto implícito, sem muita clareza e especificidade” (2016a, p. XXXVI, n. 32). Neste Prefácio, ao exemplificar um dos “voos com instrutor”, assim escreveu:

Também é o que acontece no subitem 4.5.1.2, quando, ao estudar a classificação da capacidade contributiva em absoluta ou objetiva, de um lado, e em relativa "e" subjetiva, do outro, o autor acompanha nossa interpretação, no sentido de que, se os adjetivos "absoluta" e “objetiva” são equivalentes, tal sinonímia não se verifica entre os adjetivos "relativa” e "subjetiva”, que têm, cada um deles, sentidos próprios e inconfundíveis. Quando se estabelece o tributo, adequando o seu "quantum" ao porte econômico do fato jurídico tributário, está-se atendendo à capacidade contributiva relativa; e quando se promove a adequação do tributo às circunstâncias pessoais do sujeito passivo, atenta-se para a capacidade contributiva subjetiva (2016a, p. XXXVI, grifo do autor).

Cabe, aqui, fazer menção, ainda que breve, a outros princípios: ao Princípio da Progressividade, ao Princípio da Pessoalidade, ao Mínimo Existencial e ao Princípio do NãoConfisco.

O Mínimo Existencial, que tem seu fundamento constitucional na dignidade da pessoa humana, previsto no artigo $1^{\circ}$, III, no objetivo de erradicar a pobreza e reduzir as desigualdades, mencionado no artigo $3^{\circ}$, III, e no Princípio da Capacidade Contributiva, previsto no artigo 145, § $1^{\circ}$, todos da Constituição Federal, é o limite inferior da capacidade contributiva. Trata-se, na visão de José Roberto Vieira, de “...clara alusão aos recursos suficientes para uma vida minimamente digna, satisfazendo as necessidades vitais básicas do cidadão (Constituição, art. 7, IV)” (2012, p. 196-197). O Princípio do Não-Confisco, que é de “...elevada indeterminação...”, reflete a “...tendência de impedir a destruição das riquezas gravadas pelas incidências tributárias” (1997, p. 98). O Princípio da Progressividade estabelece “...o aumento do tributo na proporção do crescimento de sua base de 
cálculo...”, e é encarado por José Roberto Vieira como decorrência do Princípio da Igualdade e da Capacidade Contributiva (1997, p. 98). O Princípio da Pessoalidade - ou da Personalização -, por sua vez, que “...toma em consideração as condições e características pessoais do contribuinte, constitui uma técnica de graduação da Capacidade Contributiva [...] estabelecendo a proporcionalidade do tributo com a capacidade contributiva subjetiva ou relativa” (2012, p. 182183).

Para terminar este tópico, mais duas breves palavras sobre temas conexos à capacidade contributiva: a extrafiscalidade e a praticabilidade. Quanto à extrafiscalidade, diz José Roberto Vieira que seu convívio com a capacidade contributiva é “...penoso e precário...”. Segundo ele, as “...primeiras experiências extrafiscais....” datam do século XVIII. Entretanto, o início do século XX é considerado como a “...fase contemporânea da utilização extrafiscal dos tributos...”. O caso clássico, julgado pela Suprema Corte Americana em 1904, é o “Estados Unidos versus McGray”, que considerou procedente a tributação mais gravosa da margarina, em comparação com a da manteiga, em razão de critérios relativos à saúde. Desde então surgiu, na doutrina estadunidense, a distinção entre o "power to tax" e o “police power”. O primeiro, atrelado à tributação com o escopo de carrear recursos financeiros para o Estado. $\mathrm{O}$ segundo, ligado à tributação com fins “...não meramente arrecadatórios, mas de caráter social ou econômico”. Extrafiscalidade, aqui. Fiscalidade, lá (2013a, p. 26-27). Por aqui, no Brasil, não há dúvidas da presença “...permanente e definitiva...” da extrafiscalidade. Entretanto, não nos escapa à percepção os problemas dela decorrentes. De acordo com José Roberto Vieira, o “...mais importante e delicado...” deles diz respeito à sua legitimidade constitucional. Os fins almejados pela utilização extrafiscal do tributo devem, necessariamente, “...encontrar nítida e clara consagração constitucional...”, sob pena de violar a capacidade contributiva e, consequentemente, a igualdade. Surgiram, então, duas correntes doutrinárias sobre o tema. A primeira delas, “...francamente avessa à extrafiscalidade...”, cujo expoente máximo é Sáinz de Bujanda, encontra-se, na visão de José Roberto Vieira, superada. A segunda, defendida por Fernando Moschetti, entende possível a conjugação da capacidade contributiva e da extrafiscalidade. Aqueles que aderem a essa tese, que é, na visão de José Roberto Vieira, “...uma explicação excessivamente simplificadora e adrede destinada a superar as contradições...”; e, ainda, “...uma tentativa talvez heroica, mas de muito difícil e mesmo impossível sustentação, sob pena de notório vilipêndio à Capacidade Contributiva”, entendem que somente se poderia cogitar de capacidade contributiva quando presente o respeito ao Princípio da Solidariedade, levando em consideração as necessidades coletivas. A visão de José Roberto Vieira sobre o tema é bem específica: na aplicação da extrafiscalidade haveria um “abrandamento” do Princípio da Capacidade Contributiva, mantendo- 
se o “...atendimento simultâneo e cumulativo...” dos seus limites mínimo e máximo, do seu "piso” e do seu "teto", quais sejam, o mínimo existencial e a proibição do efeito confiscatório. E, com o afastamento, ainda que parcial, da capacidade contributiva, não há dúvidas, há mácula, parcial, é bem verdade, da própria igualdade (2013a, p. 27-30). Como aplicar, então, a extrafiscalidade? José Roberto Vieira aponta como “precondição” o recurso à proporcionalidade. Eis suas palavras:

Trata-se do tríplice exame da proporcionalidade: verificar se as medidas escolhidas são adequadas à finalidade extrafiscal perseguida (adequação, na relação “meio $x$ fim”); se diante da existência de medidas alternativas, as adotadas são as menos restritivas e prejudiciais à igualdade (necessidade, na relação “meio $x$ fim”); e se as vantagens derivadas da finalidade extrafiscal almejada são proporcionais às desvantagens oriundas das desigualdades estabelecidas (proporcionalidade em sentido estrito, na reação “vantagens $x$ desvantagens) (2013a, p. 30-31).

Por fim, lembremo-nos de que é necessária, nesse tema, muita atenção. O vocábulo “extrafiscalidade” não deve ser encarado como “...uma palavra prestigiadora, como um vocábulo feiticeiro, a fazer com que se abrissem, para o legislador, de par em par, as portas sedutoras $e$ temíveis do arbítrio”. Esforcemo-nos para controlar, então, o “Lobo da extrafiscalidade” (2013a, p. 38).

Quanto à praticabilidade, José Roberto Vieira dedicou tópico específico sobre o tema, intitulado “Igualdade x praticabilidade” (2012, p. 183-188). Nessas páginas, José Roberto Vieira inicia o desenvolvimento do tema apresentando duas noções distintas e, até certo ponto, antagônicas, a respeito das relações da praticabilidade com a justiça fiscal. A primeira delas é do alemão HansWolfgang Arndt, da Universidade de Mannheim, para quem praticabilidade e justiça fiscal são incompatíveis. A segunda, de José Casalta Nabais, português muito lido por aqui, para quem não haveria incompatibilidade. Diante das duas concepções, escreve José Roberto Vieira: “...resta a afligir-nos a questão angustiosa e inquietante: com qual dos dois juristas se encontra a razão?”. Busquemos, então, maior aprofundamento acerca do que se trata essa tal "praticabilidade"11. Ela, de acordo com o Professor da UFPR, refere-se às “....generalizações e padronizações que, atentando para as condições normais e regulares, e abandonando as circunstâncias particulares, atípicas ou anormais, concluem pela média dos casos ou pelos tipos mais frequentes...”. O seu escopo é a chamada “...normalidade média...”. E, para alcançá-la são utilizadas presunções, ficções, indícios e normas de simplificação ${ }^{12}$. Certamente, a utilização de “técnicas padronizantes” ou, ainda,

\footnotetext{
${ }^{11}$ José Roberto Vieira alerta que a doutrina utiliza uma série de sinônimos: “Ademais de 'Praticabilidade', a doutrina utiliza outras palavras - excluindo as inexistentes em nossos léxicos -, tais como praticidade, pragmatismo, facticidade, tipificação ou estandardização" (2012, p. 185).

12 “...faça-se o registro de que as generalizações e padronizações estabelecidas pelo legislador não poderão constituir presunções absolutas (juris et de jure), inadmissíveis e insuportáveis, mas apenas presunções relativas (juris tantum),
} 
“normalizantes” não é o melhor dos mundos ${ }^{13}$. Entretanto, acredita que sejam de manejo possível, desde que em compatibilidade com o Princípio da Igualdade, “...numa atitude mais do que reverente e respeitosa, efetivamente dócil e submissa” (2012, p. 188).

\subsection{PRINCÍPIO DA SELETIVIDADE}

A alíquota, para quem indevidamente não damos muita atenção, é, vejam só, “...instrumento de realização do Princípio da Seletividade”. Na seletividade, prevista nos artigos 153, § 3º I, e 155, $\S 2^{\circ}$, III, da Constituição Federal, está a “...preocupação do legislador constitucional com a capacidade contributiva" (1993, p. 126, grifo do autor). O critério eleito pelo legislador constitucional é a essencialidade. Sobre isso não há dúvida. Poder-se-ia, entretanto, questionar os parâmetros para a aferição da essencialidade ${ }^{14}$.

Apesar de a Constituição Federal não mencionar expressamente o que considera essencial, lembremos, “...o silêncio do texto não equivale ao do contexto constitucional” (1998, p. 554). Entende José Roberto Vieira que não há outro caminho que não o de “...buscar no texto e no contexto

únicas aceitáveis, porque daquelas que admitem prova em contrário [...] Isso porque, perante os casos concretos muito diversos daquele que o legislador presumiu, diante de situações práticas que se distanciem do tipo assumido, em face de conjunturas reais que constituam claros desvios de padrão, é imperioso arredar a generalização em proveito da especificidade, é forçoso afastar a abstração em prol da concretude, é imperativo o abandonar a presunção em favor da realidade” (2012, p. 186-188). Não custa frisar, como o faz José Roberto Vieira, que as presunções são um “...terreno instável e pantanoso...” (2009, p. 487, grifo do autor). No mesmo texto, explica o que são presunções simples, para, logo após, esclarecer a sua estrutura. As presunções simples, também chamadas “do tipo simples”, “comum”, “facti” ou “hominis”, são aquelas que não são fixadas pelo legislador. Quanto à estrutura, ensina: “...dado crédito ao fato-base, dáse por confirmado o fato presumido, que, em geral, conecta-se ao primeiro. MARÍN-BARNUEVO chama o fato-base de afirmação-base, explicando-o como o fato cujo crédito permite ao órgão decisor dar crédito a outro fato; e designa o fato presumido de afirmação-resultado ou afirmação presumida, explicando-o como o fato sobre cuja veracidade se logra convicção como consequência do crédito dado à afirmação-base. Mantendo o sentido, MARIA RITA FERRAGUT opta por outra terminologia, lançando mão das expressões "fato indiciário" e "fato indiciado". E LEONARDO SPERB DE PAOLA refere o primeiro como prova indiciária, identificando-o como ponto de partida do processo mental da presunção, e o segundo como presunção propriamente dita, outorgando-lhe a condição de ponto de chegada do processo presuntivo. [...] Ainda no que tange à nomenclatura, registre-se a existência de identidade plena entre os fatos-base e o que, de hábito, chama-se de 'indícios'” (2009, p. 489, 491-493, grifo do autor). Quanto às ficções, é interessante consultarmos, também, o entendimento de José Roberto Vieira, para quem ficção jurídica é “...a providência normativa de estabelecer a identidade de dois institutos jurídicos diversos, para estender a disciplina aplicável ao primeiro também para o segundo" (2015, p. 699, grifo do autor). No mesmo texto, alerta-nos para o fato de que as ficções atentam frontalmente contra os Princípios da Tipicidade, da Legalidade, da Capacidade Contributiva e da Igualdade (2015, p. 712714).

13 "Muito embora essa inclinação generalista e padronizante, ao afastar os detalhes, as especificidades e as minúcias de cada caso, em prol da tipificação, acaba, muitas vezes, por abrandar, e mesmo, às vezes, por banir a realização da Igualdade e a identificação da real e concreta Capacidade Contributiva; há que considerar que o radicalismo inverso assume o risco de tornar a lei inexequível. [...] Eis que a Praticabilidade também opera a favor da Igualdade, uma vez que a impraticabilidade legal, sem dúvida, ofende e danifica a mesma Igualdade ” (2012, p. 187-188).

${ }^{14}$ Diz José Roberto Vieira: "Não se discute que o sentido da norma constitucional é promover uma seleção dos produtos objeto das operações que serão atingidas pelo imposto, utilizando a idéia de essencialidade como critério de seleção, para graduar a intensidade do tributo. O que se pode discutir são os parâmetros de aferição da essencialidade, a respeito dos quais silenciou o Estatuto Máximo" (1993, p. 126, grifo do autor). 
constitucionais vigentes aqueles valores ali normativamente plasmados, que permitam apurar a essencialidade de que ali se cogita" (1993, p. 127, grifo do autor). O ponto de partida para a investigação residiria na interpretação do artigo $7^{\circ}$, IV, da Constituição Federal. Lembremo-nos que, ao tratar do mínimo vital, recorremos ao artigo $7^{\circ}$, IV, a fim de individualizar aquele mínimo necessário à manutenção de vida digna por parte dos cidadãos. Nele prescreve, a Constituição, serem necessidades vitais básicas a “...moradia, alimentação, educação, saúde, lazer, vestuário, higiene, transporte e previdência social...”. Não há como deixar de reconhecer que essas necessidades, enquanto "vitais" e "básicas”, devem ser consideradas "essenciais”.

Apesar de haver dois caminhos possíveis para “...implementar a escolha dos produtos...”, é a alíquota o meio pelo qual o princípio se realiza ${ }^{15}$. E isso se dá, como ensina José Roberto Vieira, “...pelo estabelecimento das alíquotas na razão inversa da necessidade dos produtos”, ou seja, à medida que o grau de essencialidade do produto aumenta, suas alíquotas devem necessariamente diminuir, e, quanto maior o grau de superfluidade ou ainda de nocividade do produto, maior devem ser as alíquotas estabelecidas (1993, p. 127, 2006b, p. 194).

\subsection{PRINCÍPIO DA NÃO-CUMULATIVIDADE}

A Não-cumulatividade concernente ao IPI está positivada no artigo 153, § $3^{\circ}$, II, da Constituição Federal, segundo o qual o IPI “será não-cumulativo, compensando-se o que for devido em cada operação com o montante cobrado nas anteriores”. Esse é o único enunciado prescritivo constitucional que menciona expressamente a Não-cumulatividade no que se refere ao IPI, e é o principal para a revelação dos seus exatos lindes. Com efeito, do ponto de vista econômico, o IPI pode ser considerado como imposto sobre o valor agregado. Juridicamente, não. Nos impostos sobre o valor agregado, somente haverá incidência do imposto se, na operação posterior, houver um acréscimo em relação ao valor da operação anterior. Caso não haja acréscimo algum ao valor da operação subsequente, o imposto não incide.

Não é o que ocorre com o IPI, o qual se submete ao sistema de subtração indireta (imposto contra imposto). Mesmo nos casos em que o valor da operação posterior seja, em relação à operação que lhe foi precedente, menor, haverá incidência do IPI. Embora a incidência se dê sobre o valor total da operação, englobando tanto a presente quanto as que lhe foram anteriores, e não somente sobre o

\footnotetext{
${ }^{15}$ Diz José Roberto Vieira: "É certo existirem dois caminhos para implementar a escolha de produtos prescrita pelo Código Supremo: variar a base de cálculo, mantendo fixa a alíquota, ou, inversamente, fixar a base de cálculo, fazendo oscilar as alíquotas ao sabor da essencialidade/indispensabilidade dos produtos. E não é segredo que esta última foi a trilha eleita pelo legislador” (1993, p. 127, grifo do autor).
} 
valor agregado pela última, a sistemática dos créditos impede a tributação em cascata. Ou seja, mesmo que a base de cálculo seja o valor total da operação, o adquirente de insumos, produtos intermediários ou material de embalagem creditar-se-á do eventual imposto relativo às operações anteriores (2005b, p. 725).

Conquanto o artigo 153, § $3^{\circ}$, II, da Constituição Federal prescreva que o IPI “será nãocumulativo, compensando-se o que for devido em cada operação com o montante cobrado nas anteriores” [grifo nosso]; e, ainda, o artigo 49 do Código Tributário Nacional prescreva que o IPI “...é não-cumulativo, dispondo a lei de forma que o montante devido resulte da diferença a maior, em determinado período, entre o imposto referente aos produtos saídos do estabelecimento e o pago relativamente aos produtos nele entrados”, “...não é a cobrança do imposto por parte do fornecedor que legitima o crédito do adquirente” (2005b, p. 721). Eis os ensinamentos de José Roberto Vieira:

Em resumo, o direito de crédito do adquirente legitima-se pela ocorrência da operação do fornecedor. Irrelevante que nessa operação anterior o IPI tenha sido "lançado”, “cobrado” ou "pago”. Mais: irrelevante até que nessa operação anterior haja "incidido” o IPI. Basta que ela tenha existido, e que se possa quantificar, de alguma forma, o IPI que lhe seria relativo, independentemente de incidência, lançamento, cobrança ou pagamento. (2005b, p. 724).

Mas, e se uma das operações da cadeia for isenta?

$\mathrm{Na}$ verdade, o fato de uma das operações da cadeia ser isenta não gera nenhuma consequência para o direito ao crédito. Observemos que, se o vocábulo cobrado, presente no enunciado constitucional, fosse interpretado literalmente, nos casos de isenção, não haveria direito a crédito e, em razão disso, tanto a isenção quanto a Não-cumulatividade cairiam por terra.

Retomemos, aqui, as lições de José Roberto Vieira, segundo as quais, se a isenção inibir o direito ao crédito, nos tributos não-cumulativos, de isenção não se tratará, e sim de mero “diferimento" (2005b, p. 729).

Observemos o seguinte exemplo. Numa cadeia produtiva em que todos os produtos que a integram sejam tributados à alíquota de $10 \%$, e que num dos elos da cadeia haja uma isenção. Imaginemos que “A” vende insumos a "B” por R\$ 100,00 (cem reais). Sobre esse valor terá que pagar $\mathrm{R} \$ 10,00$ (dez reais) de imposto. E “B” terá direito a um crédito de $\mathrm{R}$ \$ 10,00 (dez reais). Na operação seguinte, que é isenta, “B” vende produto para “C” por R\$ 200,00 (duzentos reais). Nesse caso “B” não recolherá nada a título de imposto, na medida em que a operação é isenta. Isso não quer dizer, entretanto, que “C” não se poderá creditar de R\$ 20,00 (vinte reais). Por fim, “C” vende o produto por $\mathrm{R} \$ 300,00$ (trezentos reais). Deverá $\mathrm{R} \$ 30,00$ (trinta reais) a título de imposto, que serão pagos com o crédito de $\mathrm{R} \$ 20,00$ (vinte reais) somado a $\mathrm{R} \$ 10,00$ (dez reais) pagos em pecúnia. 
Nesse exemplo, a Não-cumulatividade foi respeitada, como também o foi a isenção. Se não houvesse como “C” se creditar dos R\$ 20,00 (vinte reais) relativos à compra de insumos de "B”, o valor de imposto por ele suportado não seria relativo tão somente à operação por ele realizada, mas também relativo à operação isenta. A isenção tornar-se-ia diferimento e a Não-cumulatividade daria lugar à cumulatividade. Nesses casos, o IPI passaria a ser um imposto sobre o valor acumulado - o valor anterior mais o valor agregado -, como ensina José Roberto Vieira (2005b, p. 726).

E outros argumentos há para que se afaste definitivamente o entendimento de que aquisições de insumos isentos - e dos beneficiados em geral - não geram direito ao crédito. Lembremo-nos que, no que respeita ao IPI, a disciplina da Não-cumulatividade é completamente diversa da do ICMS. Ora, não há, para o IPI, a imposição dos obstáculos existentes para o ICMS. Essa diferença entre a disciplina da Não-cumulatividade no ICMS e no IPI foi percebida também por José Roberto Vieira. Lembra, ainda, que o direito ao crédito decorrente da Não-cumulatividade do IPI desfruta de estatura constitucional, estando, portanto, a salvo dos ataques do legislador infraconstitucional (2005b, p. 730732).

Firmado o entendimento de que a aquisição de insumos isentos gera direito ao crédito, é de se questionar a alíquota aplicável para o cálculo do crédito decorrente dessa operação. Nesse caso, correto é o entendimento de José Roberto Vieira, de que a alíquota a ser empregada deve ser exatamente a mesma do produto final, em cujo processo produtivo se empregam os insumos, matérias-primas e produtos intermediários isentos (2005b, p. 735 et seq.).

\section{SOBRE AS FUNÇÕES DA LEI COMPLEMENTAR}

Acerca das funções da lei complementar, afirma José Roberto Vieira que há uma “...infindável querela doutrinária [...] que se arrasta há décadas...” (2013b, p. 79). O tema, de fato, é interessante. Em texto de 2008, José Roberto Vieira examina a questão, utilizando como pano de fundo a Denúncia Espontânea e as relações do Código Tributário Nacional com as prescrições do artigo 44 da Lei n. 9.430, de 27 de dezembro de 1996. Logo no início do item destinado ao exame específico do tema, alerta que empreenderá uma interpretação sistemática típica, sobre a qual já tratamos. Diz ele: “...teremos em consideração todo o ambiente normativo, no caso, todo o ambiente constitucional, mas especialmente aquelas normas fundamentais desse sistema, os princípios constitucionais”. Os princípios que, segundo ele, interessariam particularmente ao tema são i) o 
Princípio da Federação; ii) o Princípio da Autonomia Municipal; e iii) o Princípio da Isonomia das Pessoas Constitucionais (2008b, p. 399-400).

A sua principal preocupação é a noção de "normas gerais em matéria de legislação tributária”. Isso porque, é

...conceito altamente impreciso e nebuloso, instaurador de insegurança e facilitador de incursões espúrias nas competências tributárias das esferas de governo; já rigidamente traçadas pelo legislador da Constituição, numa perene e intolerável ameaça de invasão das mesmas competências e de desrespeito a tão caros princípios constitucionais como os acima enunciados (2008b, p. 401).

Firma, então, sua “...noção contextual das normas gerais tributárias, prestigiadoras dos princípios em jogo”, como aquelas normas “...de caráter declaratório, às quais cabe explicitar o que já se encontra implícito no texto constitucional, sem inovar, tão-somente se limitando a declarar, e assim, reforçando o perfil constitucional dos tributos, de modo a prevenir o surgimento de conflitos de competência” (2008b, p. 401). Em seguida, faz menção às duas principais correntes acerca das funções da lei complementar. A corrente “tricotômica”, reserva-lhe, com seu “...insistente apego à letra do Texto da Lei Mãe, três funções [...]: dispor sobre conflitos, regular limitações e estabelecer normas gerais”. A correte “dicotômica” - a quem José Roberto Vieira renomeia, lembrando-se do alerta de Maria do Rosário Esteves, de "unifuncional” - apontaria para duas funções da lei complementar: "dispor sobre conflitos e regular limitações, ambas integrantes das assim chamadas normas gerais”. O dado definitivo, segundo José Roberto Vieira, que o impede de considerar o acatamento à corrente tricotômica é a “...ausência de explicitação do modo pelo qual o art. 146, III, se compatibiliza com os elevados princípios constitucionais em questão e em perigo" (2008b, p. 402-403, grifo do autor).

Após analisar as reflexões de Heleno Taveira Tôrres, passa ao exame da posição de Humberto Ávila e dos três argumentos levantados por ele para aderir à corrente tricotômica. O primeiro argumento diz respeito ao fato de que as regras que estabelecem a competência para o estabelecimento de normas gerais devem, necessariamente, ser interpretadas em consonância com o Princípio Federativo, cujo significado surgiria no momento posterior ao da análise das outras normas que com ele mantêm conexão semântica. Em segundo lugar, defende que não é possível deixar de atribuir significado, ainda que mínimo, aos dispositivos constitucionais. E, em terceiro e último lugar, pelo fato de o Supremo Tribunal Federal ter aderido à corrente tricotômica.

José Roberto Vieira enfrenta cada um dos argumentos. Em resposta ao primeiro deles, assim escreve: 
[...] evidentemente que não basta ao princípio o significado de base, demandando-se-lhe também o significado de contexto, mas por igual evidente que essa demanda não pode ser estendida a ponto de reivindicar o excesso da interpretação do princípio em face do art. 146, III, quando cabe, isso sim, compreender este último dispositivo à luz daquele princípio; além de que o fato de ambas as normas encontrarem abrigo no texto constitucional, inclusive partilhando a mesma estrutura lógica (homogeneidade sintática) não afasta a sua colossal heterogeneidade semântica [...] cujo maior peso intensifica o seu significado normativo, reforça o seu caráter principiológico e determina sua irrecusável primazia na atividade interpretativa, fato que justa e irrecusavelmente ocorre com os princípios envolvidos neste caso. (2008b, p. 405-406, grifo do autor).

Ao segundo argumento, opõe-se José Roberto Vieira no seguinte sentido:

A tese unifuncional, esclareça-se, de saída, nunca deixou de atribuir um significado mínimo às regras do art. 146, III, que se consubstancia no reconhecimento da aplicabilidade, aqui, das duas finalidades enunciadas nos incisos anteriores: dispor sobre conflitos e regular limitações. Restaria, apenas, verificar se essa interpretação respeita o limite do texto normativo. De fato, por mais que a literalidade deva ceder passo à sistematicidade, em termos interpretativos, há que se lhe reconhecer essa condição de limite hermenêutico. (2008b, p. 406, grifo do autor).

A resposta de José Roberto Vieira ao terceiro argumento lembra-nos da função do julgador:

Diversamente dos Estados cujo ordenamento pertence à família jurídica da Common Law, em que se dá o primado da jurisprudência, o nosso integra a família romano-germânica, em que a preeminência é da lei [...]. Outra vez, abstraindo as minúcias, novamente, porque seu exame seria, aqui, inoportuno e inadequado, fiquemos com o essencial: a operação hermenêutica do julgador, a princípio identificada com a do cientista, desde que volvida para o caso concreto, porque comprometida com a produção normativa, uma vez que empenhada na tomada de decisão, visto que pressionada pela angústia do julgar, não resta, afinal, ao menos parcialmente diversa e distinta? Mais: não pede um colorido peculiar, talvez um tanto limitativo? Não exige certa matização, quiçá algo restritiva? Independente dessa resposta, que não é o local nem o momento de buscar, do que não há dúvida alguma é que, pretender que a inclinação jurisprudencial constitua fundamento bastante para acatar a teoria tricotômica, encarando-a como argumento decisivo de opção científica, consiste, no mínimo, num certo radicalismo. [...] Ora, aos juristas em geral [...] cumpre, mais do que o direito, o dever dessa mesma independência científica. Não é porque o STF acaba de decidir que só lei complementar pode dispor sobre normas gerais tributárias relativas à prescrição e à decadência, abraçando a tricotomia, - numa conclusão que, a nosso juízo, é sumamente infeliz e órfã por inteiro dos melhores fundamentos científicos - que empreenderemos fuga da arena do pensamento, permitindo a “...anestesia do senso crítico" e sucumbindo ao vício que mestre Souto identificou como "satelitização da inteligência”. Não é porque a súmula aprovada logo após essa infausta decisão vincula os “...demais órgãos do Poder Judiciário...” e a “...a administração pública direta e indireta..." (CF, art. 103-A), que nos daremos nós como cientificamente vinculados, abdicando, assim, de nossa autonomia intelectual e passando a gravitar em torno das concepções da jurisprudência! Tal atitude corresponderia a um autêntico pedido de demissão da Ciência do Direito, pois o comportamento dócil e acrítico que conduz ao imobilismo, à estagnação e à inércia, definitivamente não se harmoniza com o mínimo de cientificidade [...]. (2008b, p. 409-411, grifo do autor).

Neste mesmo texto, José Roberto Vieira reconhece que a observação de Humberto Ávila o incitou a pensar e a repensar o posicionamento no que se refere à parte final do artigo 146, III, da Constituição Federal. Para José Roberto Vieira não parece que as normas gerais em matéria de 
legislação tributária, veiculadas por meio de lei complementar, limitam-se a apenas dispor estritamente sobre conflitos de competência e a regular limitações constitucionais da competência tributária. Incumbe-lhes também dispor sobre o que preveem as alíneas “c” e “d”, e o parágrafo único do inciso III do artigo 146 da Constituição Federal, em razão das particularidades dos temas que encerram (2008b, p. 407). E, em texto de 2016, em que revisita o tema sob “...novíssima perspectiva...”, lembra do artigo 146-A, acrescido pelo texto da Emenda Constitucional n. 42, de 19 de dezembro de 2003, para então concluir: “Admita-se, portanto, no âmbito da função de estabelecer normas gerais tributárias, do artigo 146, ademais das finalidades de dispor sobre conflitos (inciso I) e de regular limitações (inciso II), uma terceira finalidade para abranger esses objetivos específicos (artigo 146, inciso III, alíneas c e d, e parágrafo único; e artigo 146-A)” (2016c, p. 706, grifo do autor).

\section{CONCLUSÃO}

A partir da análise da obra de José Roberto Vieira, percebemos que ela praticamente examina todos os temas do direito constitucional tributário, tais como o da interpretação, o da noção de sistema, o da criação constitucional do tributo e o da competência tributária, bem como suas características, o dos princípios constitucionais tributários e o das funções da lei complementar.

Entende que a função da Ciência do Direito é a de explicar, e não meramente descrever, o Direito Positivo. A interpretação do direito, em sua visão, deve ser sistemática, e não apenas literal. E, para levarmos a cabo essa atividade, é possível nos valermos das ferramentas da semiótica, analisando o discurso jurídico em seus planos sintático, semântico e pragmático.

Ao tratar da competência tributária, traz contribuições relevantes para a doutrina nacional, ao desenvolver o raciocínio de que não existe um verdadeiro poder tributário e de que a Constituição cria o tributo. E identifica como características da competência tributária a indelegabilidade, a irrenunciabilidade, a incaducabilidade, a inalterabilidade e a facultatividade.

No que se refere aos princípios, que para ele são pressupostos inafastáveis da atividade interpretativa, muitas foram suas contribuições. Realizou profundo exame dos princípios da República, da Federação, da Autonomia dos Municípios e da Tripartição das Funções. Quanto aos princípios constitucionais gerais, são profundas as suas lições sobre o princípio da legalidade, examinando as suas possíveis atenuações, bem como o regime constitucional da medida provisória, e, ainda, os avanços e retrocessos trazidos pela Emenda Constitucional n. 32, de 11 de setembro de 2001. Relevantes, também, seu exame acerca da manifestação da igualdade em matéria tributária. De 
fato, o exame realizado por ele sobre o princípio da capacidade contributiva é completo, principalmente ao traçar a distinção entre capacidade contributiva absoluta ou objetiva, capacidade contributiva subjetiva e capacidade contributiva relativa. O mesmo pode ser dito a respeito de suas reflexões sobre as relações entre a capacidade contributiva e a extrafiscalidade e a praticabilidade. E, também, das manifestações da capacidade contributiva no ICMS e no IPI, ou seja, o princípio da seletividade e da não-cumulatividade.

E, por fim, ao aderir à corrente unifuncional, entende que são funções da lei complementar estabelecer normas gerais em matéria de legislação tributária, que não se limitam a apenas dispor estritamente sobre conflitos de competência e a regular limitações constitucionais da competência tributária. Incumbe-lhes também dispor sobre o que preveem as alíneas “c” e “d”, e o parágrafo único do inciso III do artigo 146, e o artigo 146-A da Constituição Federal.

Deste artigo, no entanto, ficaram de fora as concepções dele acerca da teoria da norma tributária, bem como suas reflexões a respeito do IPI, do Imposto de Renda Pessoa Jurídica, do Imposto de Renda Pessoa Física e do Direito Penal Tributário.

As confiáveis obras de José Roberto Vieira - o grande nome do Direito Tributário do Paraná, e um dos maiores do Brasil -, que influenciaram mais de uma geração de tributaristas brasileiros, merecem lugar de destaque na doutrina nacional. Suas lições em muito ultrapassam os limites territoriais do estado do Paraná, alcançando não apenas os privilegiados acadêmicos da Universidade Federal do Paraná que o têm como mestre em sala de aula.

\section{REFERÊNCIAS}

BARBOSA, Rui. Oração aos moços. São Paulo: Editora Papagaio, 2003.

BORGES, José Souto Maior. Ciência feliz. 2. ed. São Paulo: Max Limonad, 2000.

BORGES, José Souto Maior. La educación para la libertad (dedicado a José Roberto Vieira). In: BORGES, José Souto Maior. Ciencia feliz (primera edición en español). Lima: Palestra Editores, 2012.

BORGES, José Souto Maior. O direito como fenômeno lingüístico, o problema de demarcação da ciência jurídica, sua base empírica e o método hipotético-dedutivo. In: Anuário do Mestrado em Direito, v. 4. Recife: UFPE-CCJ-FDR, 1988, p. 11-58.

MONTESQUIEU, Charles de Secondat. O espírito das leis. São Paulo: Martins Fontes, 1996. 
VIEIRA, José Roberto. A Extrafiscalidade da Lei 12.715/2012 e a Capacidade Contributiva: A Convivência do Lobo e do Cordeiro? Revista de Direito Tributário, São Paulo, v. 118, 2013a, p. 18-42.

VIEIRA, José Roberto. A noção de sistema no Direito. Revista da Faculdade de Direito UFPR, Curitiba, v. 33, 2000, p. 53-64. Disponível em: <https://goo.gl/QWxuBk>. Acesso em: 17 jun. 2017.

VIEIRA, José Roberto. A regra-matriz da incidência do IPI: texto e contexto. Curitiba: Juruá, 1993.

VIEIRA, José Roberto. A Semestralidade do PIS: Favos de Abelha ou Favos de Vespa? Revista Dialética de Direito Tributário, São Paulo, v. 83, 2002a, p. 88-106.

VIEIRA, José Roberto. Apropriação Indébita Tributária no IPI e no ICMS: Vislumbres de um Estado “Shylock". In: BARRETO, Aires F. et al. (Org.). Direito Tributário, Linguagem e Método: As Grandes Disputas entre Jurisprudência e Dogmática na Experiência Brasileira Atual. São Paulo: Noeses, 2008a.

VIEIRA, José Roberto. Bocage e o Terrorismo Constitucional das Medidas Provisórias Tributárias: A Emenda Pior do que o Soneto. In: FERRAZ, Roberto (Org.). Princípios e Limites da Tributação. São Paulo: Quartier Latin, 2005a.

VIEIRA, José Roberto. Crédito de IPI relativo a operações anteriores beneficiadas: maiô completo ou completa nudez. In: DE SANTI, Eurico Marcos Diniz (Coord.). Curso de especialização em direito tributário: estudos analíticos em homenagem a Paulo de Barros Carvalho. Rio de Janeiro: Forense, 2005b.

VIEIRA, José Roberto. Crédito Presumido do IPI na Industrialização por Encomenda: Um Estado “Maquiaveliano" e talvez "Maquiavélico". In: MACEDO, Alberto et al. Sistema Tributário Brasileiro e a Crise Atual. São Paulo: Noeses, 2009, p. 451-519.

VIEIRA, José Roberto. Denúncia espontânea e multa moratória: confissão e crise na "jurisdição" administrativa. In: GUNTHER, Luiz Eduardo (Coord.). Jurisdição: crise, efetividade e plenitude institucional. Curitiba: Juruá, 2008b.

VIEIRA, José Roberto. Direitos Fundamentais e Reforma Tributária: Esse Obscuro e Ardiloso Objeto do Desejo. In: SANTI, Eurico Marcos Diniz de (Org.). Tributação e Desenvolvimento: Homenagem ao Professor Aires Barreto. São Paulo: Quartier Latin, 2011.

VIEIRA, José Roberto. E, afinal, a Constituição cria tributos! In: TÔRRES, Heleno Taveira (Coord.). Teoria geral da obrigação tributária: estudos em homenagem ao professor José Souto Maior Borges. São Paulo: Malheiros, 2005c.

VIEIRA, José Roberto. Em busca da verdade sobre o IPI: dos voos com instrutor aos voos solos ousados. In: VALLE, Maurício Dalri Timm do. Princípios constitucionais e regras-matrizes de incidência do Imposto sobre Produtos Industrializados - IPI. São Paulo: Noeses, 2016a.

VIEIRA, José Roberto. Equiparações de estabelecimentos a industriais por decreto: portas de papelão na fortaleza de pedra da legalidade! A\&C. Revista de Direito Administrativo \& Constitucional (Impresso), ano 16, n. 65, 2016b, p. 159-197. 
VIEIRA, José Roberto. Equiparações de Estabelecimentos Comerciais a Industriais: Ficções que Tangem o Divino ou que Tocam o Demoníaco? In: MACEDO, Alberto et al. (Org.). Direito Tributário e os Novos Horizontes do Processo. São Paulo: Noeses, 2015.

VIEIRA, José Roberto. Fundamentos Republicano-Democráticos da Legalidade Tributária: Óbvios Ululantes e Não Ululantes. In: FOLMANN, Melissa (Org.). Tributação e Direitos Fundamentais: Propostas de Efetividade. Curitiba: Juruá, 2006a.

VIEIRA, José Roberto. Imposto sobre Produtos Industrializados: Atualidade, Teoria e Prática. In: CARVALHO, Paulo de Barros (Org.). Justiça Tributária: Direitos do Fisco e Garantias do Contribuinte nos Atos da Administração e no Processo Tributário. São Paulo: Max Limonad, 1998.

VIEIRA, José Roberto. Imposto sobre Produtos Industrializados: Uma Águia Garciamarquiana entre os Tributos. In: SANTI, Eurico Marcos Diniz de; ZILVETI, Fernando Aurelio; MOSQUERA, Roberto Quiroga (Org.). Tributação das Empresas: Curso de Especialização. São Paulo: Quartier Latin, 2006b.

VIEIRA, José Roberto. IPI X ICMS e ISS: conflitos de competência ou sedução das aparências? In: SANTI, Eurico Marcos Diniz de; CANADO, Vanessa Rohal (Coord.). Tributação do setor industrial. São Paulo: Saraiva, 2013b.

VIEIRA, José Roberto. Legalidade e Norma de Incidência: Influxos Democráticos no Direito Tributário. In: GRUPENMACHER, Betina Treiger et al. (Org.). Tributação: Democracia e Liberdade - Em Homenagem à Ministra Denise Martins Arruda. São Paulo: Noeses, 2014a.

VIEIRA, José Roberto. Legalidade Tributária e Medida Provisória: Mel e Veneno. In: FISCHER, Octavio Campos (Org.). Tributos e Direitos Fundamentais. São Paulo: Dialética, 2004.

VIEIRA, José Roberto. Legalidade Tributária ou Lei da Selva: Sonho ou Pesadelo. Revista da Faculdade de Direito UFPR, Curitiba, v. 37, n. 0, 2002b, p. 5-22.

VIEIRA, José Roberto. Medidas provisórias em matéria tributária: as catilinárias brasileiras. 1999. Tese (Doutorado em Direito) - Pontifícia Universidade Católica de São Paulo, São Paulo, 1999.

VIEIRA, José Roberto. Medidas Provisórias Tributárias e Segurança Jurídica: A Insólita Opção Estatal pelo "Viver Perigosamente". In: BARRETO, Aires F. et al. (Org.). Segurança Jurídica na Tributação e Estado de Direito. São Paulo: Noeses, 2005d.

VIEIRA, José Roberto. Normas Gerais de Direito Tributário: Um Velho Tema sob Novíssima Perspectiva. In: CARVALHO, Paulo de Barros (Coord.); SOUZA, Priscila de (Org.). 50 Anos do Código Tributário Nacional. São Paulo: Noeses, 2016c.

VIEIRA, José Roberto. O IRPF e o direito fundamental à igualdade: um tributo de dupla personalidade! In: BRANCO, Paulo Gonet; MEIRA, Liziane Angelotti; CORREIA NETO, Celso de Barros (Org.). Tributação e direitos fundamentais conforme a jurisprudência do STF e do STJ. São Paulo: Saraiva, 2012.

VIEIRA, José Roberto. O princípio da federação, Soares de Melo e uma obra ‘Federal’! [inédito]. 
VIEIRA, José Roberto. O Princípio da Legalidade da Administração. Revista de Direito Público, v. 97, 1991, p. 143-149.

VIEIRA, José Roberto. Pelos Velhos Caminhos do IRPJ, do Conceito de Renda e da Compensação de Prejuízos, sob Novas (?) Luzes: Uma Epopeia Tributária! In: MOREIRA, André Mendes et al. (Org.). O Direito Tributário: Entre a Forma e o Conteúdo. São Paulo: Noeses, 2014b.

VIEIRA, José Roberto. Princípios constitucionais e estado de direito. Revista de Direito Tributário, São Paulo, ano 14, n. 54, out./dez. 1990, p. 95-104.

VIEIRA, José Roberto. Reforma tributária: de Salomão a Souto, uma armadilha. Revista de Direito Tributário, São Paulo, n. 72, 1996, p. 112-115.

VIEIRA, José Roberto; FABO, Diego Marín Barnuevo. Direito Constitucional Tributário Comparado: Brasil e Espanha. Revista de Direito Tributário, São Paulo, ano 18, n. 68, 1997, p. 95100.

WARAT, Luís Alberto. O direito e sua linguagem. 2. ed. aum. Porto Alegre: Fabris, 1995.

Maurício Dalri Timm do Valle Bacharel, Mestre e Doutor em Direito pela Universidade Federal do Paraná (UFPR). Professor no Programa de Pós-Graduação Stricto Sensu em Direito da Universidade Católica de Brasília (UCB). Assessor de Ministro do Supremo Tribunal Federal. E-mail: mauricio_do_valle@hotmail.com 